\title{
Revealing structure and mechanism of Palladium during direct synthesis of hydrogen peroxide in continuous flow using operando spectroscopy
}

\author{
Manuel Selinsek, ${ }^{a, *}$ Benedikt J. Deschner, ${ }^{a}$ Dmitry E. Doronkin,, ${ }^{b, c}{ }^{*}$ Thomas L. \\ Sheppard, ${ }^{\mathrm{b}, \mathrm{c}}$ Jan-Dierk Grunwaldt, ${ }^{\mathrm{b}, \mathrm{c}}$ Roland Dittmeyer, ${ }^{\mathrm{a}, \mathrm{b}}$ \\ anstitute for Micro Process Engineering, KIT, Eggenstein-Leopoldshafen, 76344, Germany \\ 'Institute of Catalysis Research and Technology, KIT, Eggenstein-Leopoldshafen, 76344, Germany \\ 'Institute for Chemical Technology and Polymer Chemistry, KIT, Karlsruhe, 76131, Germany \\ *Corresponding authors: manuel.selinsek2@kit.edu, dmitry.doronkin@kit.edu
}

\begin{abstract}
The direct synthesis of $\mathrm{H}_{2} \mathrm{O}_{2}$ is a dream reaction in the field of selective oxidation and green chemical synthesis. However, the unknown active state of the catalyst and the lack of a defined catalytic mechanism preclude the design and optimization of suitable catalysts and reactor setups. Here direct synthesis of $\mathrm{H}_{2} \mathrm{O}_{2}$ over $\mathrm{Pd}-\mathrm{TiO}_{2}$ in water was investigated in a continuous flow reactor setup utilizing undiluted oxygen and hydrogen to increase aqueous phase concentrations safely at ambient temperature and a pressure of 10 bars. In this experiment operando X-ray Absorption Spectroscopy (XAS) and online flow injection analysis for photometric quantification of $\mathrm{H}_{2} \mathrm{O}_{2}$ were combined to build catalyst structure-activity relationships in direct $\mathrm{H}_{2} \mathrm{O}_{2}$ synthesis. XAS at the $\mathrm{Pd} \mathrm{K}$ absorption edge was used to observe oxidation state and local $\mathrm{Pd}$ structure together with $\mathrm{H}_{2} \mathrm{O}_{2}$ production for three reactant ratio $\left(\mathrm{H}_{2} / \mathrm{O}_{2}\right)$ regimes: hydrogen rich $(>2)$, hydrogen lean $(<0.5)$ and balanced $(0.5-2)$. During $\mathrm{H}_{2} \mathrm{O}_{2}$ production, oxygen was only found adsorbed on the surface of Pd nanoparticles and hydrogen was found dissolved in bulk palladium hydride ( $\alpha$-phase) indicating a reaction of surface oxygen with lattice hydrogen to form hydrogen peroxide. Under hydrogen rich conditions, formation of $\beta$-phase palladium hydride was found to coincide with zero $\mathrm{H}_{2} \mathrm{O}_{2}$ yield. This constitutes an operando study of direct $\mathrm{H}_{2} \mathrm{O}_{2}$ synthesis under elevated partial pressures of $\mathrm{H}_{2}$ and $\mathrm{O}_{2}$ in continuous flow. The results obtained will aid in rational design of future catalysts and optimization of process parameters, bringing the concept of a viable, efficient process for $\mathrm{H}_{2} \mathrm{O}_{2}$ synthesis one step closer to reality.
\end{abstract}

Keywords: $\mathrm{H}_{2} \mathrm{O}_{2}$, direct synthesis, operando, X-ray absorption spectroscopy, Pd, hydride 


\section{TOC graphics:}

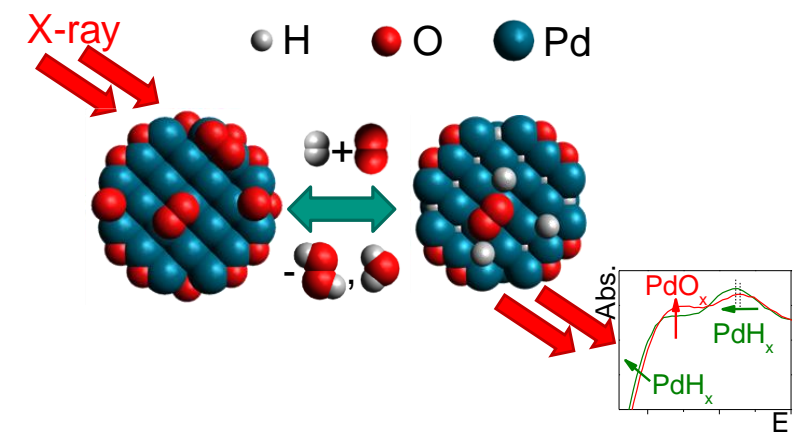

\section{Introduction}

Hydrogen peroxide holds unique advantages in the field of chemistry as a powerful, selective and environmentally benign oxidizing agent. Currently hydrogen peroxide is produced on industrial scale by the anthraquinone $(A Q)$ process. The $A Q$ process is energy intensive and involves several complex steps consisting of hydrogenation, oxidation, recycling, extraction and distillation, and is therefore only viable on a large scale. In addition, the large quantities of concentrated and highly reactive $\mathrm{H}_{2} \mathrm{O}_{2}$ solutions produced have to be stored and transported, after which they are usually diluted once more at the point of use. Consequently an on-site production method for generating $\mathrm{H}_{2} \mathrm{O}_{2}$ solutions with a specified reaction medium and concentration is highly desirable [1]. A potential alternative route for $\mathrm{H}_{2} \mathrm{O}_{2}$ production is the direct catalyzed reaction of $\mathrm{H}_{2}$ and $\mathrm{O}_{2}$ in the liquid phase. Direct synthesis itself is a dream reaction with $100 \%$ atom economy, minimal use of hazardous solvents or additives, and essentially zero harmful waste. Although direct synthesis has been the subject of extensive research [1-5], a production process with high productivity and long-term stability is still missing. Improving availability and decreasing cost of $\mathrm{H}_{2} \mathrm{O}_{2}$ through direct synthesis pathways will foreseeably promote widespread use of this powerful oxidant for a range of processes, while directly producing only water as a byproduct. Therefore realization of a commercially viable process for direct $\mathrm{H}_{2} \mathrm{O}_{2}$ synthesis has the potential to revolutionize the chemical industry, from an environmental and green chemistry perspective [6].

One main issue hindering the uptake of direct $\mathrm{H}_{2} \mathrm{O}_{2}$ synthesis as a viable process is low selectivity. This challenging aspect arises from the fact that $\mathrm{H}_{2} \mathrm{O}_{2}$ is a thermodynamically unfavored and highly reactive intermediate in the reaction network. Therefore, selectivity is defined not only by water formation as a side reaction, but more importantly due to consecutive hydrogenation and decomposition of $\mathrm{H}_{2} \mathrm{O}_{2}$ to water, as shown in equations 1-4. In order to stabilize and boost the yield of desired product, several techniques were developed to increase the selectivity, which include addition of sodium bromide as promoter, addition of phosphoric and/or sulfuric acid to lower the $\mathrm{pH}$ value, passivation of steel equipment by acid treatment, and keeping the temperature below $50{ }^{\circ} \mathrm{C}$ to prevent auto decomposition $[3,4]$.

$\mathrm{H}_{2}+\mathrm{O}_{2} \rightarrow \mathrm{H}_{2} \mathrm{O}_{2}$ 
$2 \mathrm{H}_{2}+\mathrm{O}_{2} \rightarrow 2 \mathrm{H}_{2} \mathrm{O}$

$\mathrm{H}_{2} \mathrm{O}_{2}+\mathrm{H}_{2} \rightarrow 2 \mathrm{H}_{2} \mathrm{O}$

$\mathrm{H}_{2} \mathrm{O}_{2} \rightarrow \mathrm{H}_{2} \mathrm{O}+0.5 \mathrm{O}_{2}$

The low selectivity towards $\mathrm{H}_{2} \mathrm{O}_{2}$ is the focus of ongoing extensive research on catalyst development. The catalysts studied for direct synthesis are mainly noble metals or noble metal alloys on a variety of inorganic supports, i.e. alumina, carbon, silica and titania [1]. Pd was found to be very active for the synthesis of $\mathrm{H}_{2} \mathrm{O}_{2}$, but also very active for subsequent hydrogenation and decomposition. Better performances were obtained by alloying $\mathrm{Pd}$ with $\mathrm{Au}$ or Sn $[7,8]$. Moreover, it was shown that pre-treatments including oxidation, reduction and impregnation with acid of the supported $\mathrm{Pd}$ change the catalytic behavior. However, it is an open question whether metallic or oxidic $\mathrm{Pd}$ favors $\mathrm{H}_{2} \mathrm{O}_{2}$ formation and how acids and promoters are involved in the reaction $[4,9]$. A recent study by Like et al. revealed that the reaction might take place at the interface between $\mathrm{Pd}$ and $\mathrm{PdO}$ indicating the strong dependence on both phases [10,11]. In addition surface and subsurface impurities such as $\mathrm{C}, \mathrm{N}$ and $\mathrm{O}$ were suggested to limit the uptake of hydrogen in $\mathrm{Pd}$ and thereby increasing the selectivity to $\mathrm{H}_{2} \mathrm{O}_{2}$ [12]. A similar effect is most likely achieved by surface species such as PVA, $\mathrm{CO}_{2}, \mathrm{SO}_{4}{ }^{2-}$ [13]. This also led to the conclusion that subsurface hydrogen might play a crucial role in direct synthesis of $\mathrm{H}_{2} \mathrm{O}_{2}$ [14]. Tien et al. studied the influence of the particle size and found that Pd NPs with a diameter of 1.4 $\mathrm{nm}$ achieved the best catalytic performance while single site Pd NPs were inactive, further indicating an important interaction between surface and subsurface domains [15]. On the other hand, Schlögl et al. found that sintering of Pd nanoparticles is responsible for total hydrogenation to water and needs to be prevented to maintain high selectivity [16]. In order to incorporate the acidic function in the catalyst $\mathrm{Pd}$ supported on ordered mesoporous carbon doped with heteropolyacids (HPA) was recently studied by Lee et al. who found increasing selectivity and productivity with increasing HPA content/acidity [17]. Similarly, Blanco-Brieva et al. reported that catalytic performance increases with acidity of the support with $\mathrm{Pd}$ supported on silica functionalized with aryl sulfonic, alkyl phosphonic and alkyl carboxylic groups [18]. Furthermore structural modifications of the support material are known to influence catalyst performance as well. Studies on $\mathrm{Pd} / \mathrm{TiO}_{2}$ modified with heterogeneous carbon [19] and core-shell structured $\mathrm{Pd} / \mathrm{SiO}_{2}$ with a microporous $\mathrm{Si}$ shell on silica beads [20] showed an increased catalytic performance with decreased adsorption/residence time of $\mathrm{H}_{2} \mathrm{O}_{2}$.

The challenging aspects of the reaction also led to novel reaction engineering concepts aimed at enhancing process control and boosting $\mathrm{H}_{2} \mathrm{O}_{2}$ productivity. Many types of reactors, including trickle beds, micro reactors and membrane reactors have been studied in order to increase productivity in a continuous flow process [21-26]. It should be noted that while Hutchings et al. reported that a $\mathrm{Pd}$-Au catalyst retained $>98 \% \mathrm{H}_{2} \mathrm{O}_{2}$ selectivity after 98 hours of reaction in batch operation [27], long term stability of a catalyst producing $\mathrm{H}_{2} \mathrm{O}_{2}$ with sufficient selectivity and productivity is still a primary concern for continuous flow operation [28]. The reaction mechanism of the direct synthesis is usually studied by activity tests in autoclaves [29-31]. However, it is difficult to derive aspects of the reaction mechanism because of the complex transport phenomena in the triphasic gas-liquid-solid system overshadowing the intrinsic kinetics [2]. By isotope labeling it was proven that diatomic oxygen species adsorbed on Pd react to $\mathrm{H}_{2} \mathrm{O}_{2}$, whereas water formation takes places via oxygen dissociation [2]. This is in line with Density 
Functional Theory (DFT) calculations on Pd clusters and Au clusters, where formation of adsorbed $\mathrm{OOH}^{*}$ was found to be the rate limiting step [32,33]. DFT calculations on $\mathrm{Pd} / \mathrm{Au}$ alloys showed that $\mathrm{Au}$ blocks the dissociation of $\mathrm{O}_{2}$ leading to enhanced selectivity as observed experimentally [34]. In most kinetic studies it is a common opinion that hydrogen also reacts from an adsorbed state. In contrast, Wilson et al. [30] have recently found that the oftensuggested Langmuir-Hinshelwood mechanism was not able to describe their experimental data for direct synthesis of $\mathrm{H}_{2} \mathrm{O}_{2}$ on palladium clusters. Furthermore, they showed that $\mathrm{H}_{2} \mathrm{O}_{2}$ is likely formed by reaction pathways that involve intermediates not present on the catalyst surface. They suggested a heterolytic reaction pathway, where adsorbed oxygen is reduced with electrons released by hydrogen oxidation. The reduced surface oxygen then forms $\mathrm{H}_{2} \mathrm{O}_{2}$ by reacting with dissolved $\mathrm{H}^{+}$present in the solvent formed by hydrogen oxidation on the $\mathrm{Pd}$ surface. Their approach was based on the observation that formation of $\mathrm{H}_{2} \mathrm{O}_{2}$ only occurs in protic solvents.

While kinetic investigations with complementary computational modeling studies are crucial for getting insight on the general behavior of the catalytic system, providing empirical data on the structure, behavior and mechanism of the active material is a challenge best addressed using in situ / operando spectroscopy. X-ray Absorption Spectroscopy (XAS) using synchrotron radiation has evolved into a powerful tool in the field of catalysis, offering an element-specific probe of electronic structure and local coordination environment [35]. The high penetration of hard X-rays enables in situ study of materials under practically any environmental conditions such as temperature or pressure which may be required. A spectroscopic approach is important to define parameters such as metal oxidation state, local coordination environment, and behavior under reaction conditions. Such an approach has already been demonstrated for several $\mathrm{Pd}$-catalyzed reactions in liquid phase. However, for direct $\mathrm{H}_{2} \mathrm{O}_{2}$ synthesis a continuous system has to be especially designed, in order to observe the catalyst during stable reaction conditions, including elevated pressures and variable gas ratios [36,37]. Such an experiment was reported for the first time by Centomo et al. [38], who investigated a Pd/K2621 catalyst in a continuous flow cell at room temperature and 1 bar pressure. However, activity data and steady state results were not presented. In this study the aim was to significantly increase productivity of the reaction to a detectable level of $\mathrm{H}_{2} \mathrm{O}_{2}$. To achieve this, a reaction setup was designed to utilize undiluted reactants at 10 bar pressure, thereby increasing the reactant concentration in the liquid phase. Operando XAS and online flow injection analysis for photometric quantification of $\mathrm{H}_{2} \mathrm{O}_{2}$ were then combined to assess the performance of a $\mathrm{Pd} / \mathrm{TiO}_{2}$ catalyst in a flow cell under varying experimental parameters, including flow rate and reactant ratio $\left(\mathrm{H}_{2} / \mathrm{O}_{2}\right)$ in the liquid phase. Consequently, for the first time it was possible to combine empirical data of structure and activity of a palladium catalyst during direct synthesis of $\mathrm{H}_{2} \mathrm{O}_{2}$ under more realistic reaction conditions. Therefore, the results presented here open up the opportunity towards a sophisticated optimization of future reaction systems and specialized catalysts in order to make this valuable chemical reaction more generally available for society and industry. 


\section{Materials and methods}

\section{Catalyst preparation}

$\mathrm{Pd} / \mathrm{TiO}_{2}$ was chosen as catalyst system for this work since $\mathrm{TiO}_{2}$ has the necessary properties to function as a support in continuous experiments. It is known for exhibiting strong metal-support interaction and therefore keeping Pd well dispersed, additionally it is very stable in water and gives excellent selectivity while having high reaction rates as described by the literature [39,40]. A 1 wt. $\% \mathrm{Pd} / \mathrm{TiO}_{2}$ catalyst was prepared for direct synthesis of $\mathrm{H}_{2} \mathrm{O}_{2}$ according to a wet impregnation method reported by Inoue et al. [39]. For this purpose, $167 \mathrm{mg} \mathrm{PdCl}_{2}$ (Sigma Aldrich, $99 \%$ ) was dissolved in a $100 \mathrm{ml} 1 \mathrm{M}$ aqueous hydrochloric acid solution before addition of $10 \mathrm{~g} \mathrm{TiO}_{2}$ (Nanostructured \& Amorphous Materials Inc., $50 \mathrm{~nm}$ APS, $99.9 \%$ ) rutile phase confirmed by XRD - see Figure S1, (Supporting Information, SI) particles under stirring. Then the suspension was dried over a hot plate until evaporation of all liquid was completed and only a solid phase remained. The solid was then pestled and calcined in air at $350{ }^{\circ} \mathrm{C}$ for 6 hours. Afterwards the material was reduced in 5 vol.- $\% \mathrm{H}_{2}$ in $\mathrm{Ar}$ for 3 hours at $350{ }^{\circ} \mathrm{C}$. Finally, the powder was pressed and sieved to a primary particle size fraction of 100 to 250 microns before further use. No residual $\mathrm{Cl}$ was found in the final catalyst by Energy-Dispersive X-ray spectroscopy (EDX analysis, cf. SI, section S2).

\section{Catalyst characterization}

Metal content analysis was performed by inductively coupled plasma optical emission spectroscopy (ICP-OES, Agilent 725). Therefore a sample of the liquid product solution was collected from the reactor effluent following reaction. As reference, a sample of the fresh feed solution was collected after preparation. For (scanning) transmission electron microscopy (S)TEM, powder samples of $1 \mathrm{wt} . \% \mathrm{Pd} / \mathrm{TiO}_{2}$ were ground in a mortar and loaded dry onto copper grids (200 mesh) covered with holey carbon film. The catalyst specimens were examined in a FEl Titan 80-300 aberration-corrected electron microscope operated at $300 \mathrm{kV}$. STEM images were acquired by a Fischione model 3000 HAADF STEM detector. Catalysts were measured: (i) following calcination at $350{ }^{\circ} \mathrm{C}$ in air for 6 hours, (ii) following pre-reduction at 350 ${ }^{\circ} \mathrm{C}$ in 5 vol.-\% $\mathrm{H}_{2}$ in Ar for 3 hours, (iii) following in situ XAS studies at DESY P65. Particle size distribution for $\mathrm{Pd}$ was determined by manual counting of approximately 200 particles for each sample using ImageJ software [41].

\section{Experimental setup, reaction cell and procedure}

The experimental setup used to conduct the direct synthesis of $\mathrm{H}_{2} \mathrm{O}_{2}$ in continuous mode is schematically shown in Figure 1a. and photos are available in Figure S5. The design with two separate and independent vessels offers two main benefits. Firstly, since both reactants are independently fed to the cell in a dissolved state, explosive gas mixtures of hydrogen and oxygen are circumvented and pure gases can be utilized. Thereby the reactant concentration can be significantly increased in a safe manner. Secondly, this also allows easy control over the hydrogen to oxygen ratio by being able to vary the flow rate of the micro gear pumps (HNP Mikrosysteme, mzr7205). The essential parts are two $5 \mathrm{~L}$ stainless steel vessels each filled with 
$2 \mathrm{~L}$ of demineralized water and $5 \mathrm{mM} \mathrm{NaBr}$ as promoter. The setup was tested for blind activity using $5 \mathrm{mM} \mathrm{NaBr}$ in water as solvent in our laboratory. It was not found to produce $\mathrm{H}_{2} \mathrm{O}_{2}$. However, it was found that $\mathrm{H}_{2} \mathrm{O}_{2}$ decomposition occurs on stainless steel equipment in water without $\mathrm{NaBr}$. Therefore a passivation procedure [42] was applied to all stainless steel parts and $5 \mathrm{mM} \mathrm{NaBr}$ was added to prevent any decomposition in stainless steel equipment. After both vessels were filled with the reaction medium, they were consecutively pressurized 3 times to 10 bar, one vessel with pure hydrogen and one vessel with pure oxygen (technical grade) in order to flush out any remaining air. After the desired pressures were adjusted, the reaction media were saturated with the respective gases, hydrogen or oxygen, by pumping the liquids with micro gear pumps from the bottom of each vessel to dip tubes inserted at the top, where the liquids were dispersed in the gas zones through nozzles. Saturation was assumed after cycling the liquid in each vessel for 1 hour with a flow rate of $200 \mathrm{~mL} / \mathrm{min}$. The saturated liquids were then mixed in a T-piece and fed to the reaction cell using the same micro gear pumps. Check valves were installed after each pressure valve to prevent mixing of $\mathrm{O}_{2}$ and $\mathrm{H}_{2}$ in any of the pressurized vessels. The pressure in the cell was regulated at 11 bar using a needle valve, to give the pumps a differential pressure for proper functionality. Temperature and pressure were measured at the inlet and outlet of the cell. The experimental setup described above was designed with the aim of being readily portable for use at synchrotron radiation facilities. A partially modified setup was also used during laboratory tests, as discussed towards the end of this section.
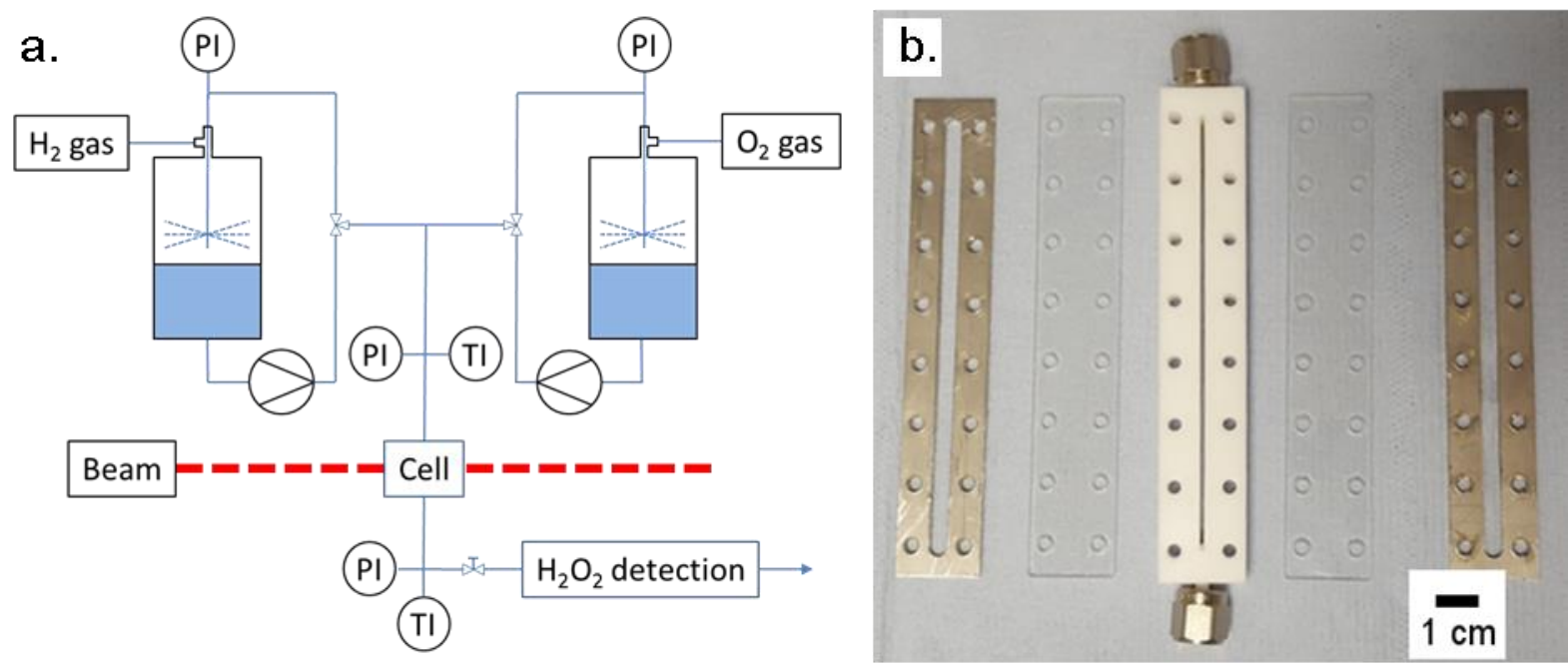

Figure 1. (a.) Overview of the experimental setup for continuous direct synthesis of $\mathrm{H}_{2} \mathrm{O}_{2}$ with pressure indication $(\mathrm{PI})$ and temperature indication ( $\mathrm{TI}$ ) and (b.) fixed bed in situ cell for operando XAS.

The reaction cell for operando XAS experiments is shown in Figure 1b. It consists of a PTFE body with a $100 \mathrm{~mm}$ long, $1 \mathrm{~mm}$ wide and $10 \mathrm{~mm}$ deep slit to hold a fixed bed of granulated catalyst. At the entry and exit of the slit, $3 \mathrm{~mm}$ tubular adapters where placed on the outside for a connection with the reaction stream. The open top and bottom of the slit were covered with 2 $\mathrm{mm}$ thick polycarbonate plates and screwed together with metal frames to be tightened against 
the elevated pressure. Note that using such thick polycarbonate as window material is possible only when measuring at high energies such as around $\mathrm{Pd} \mathrm{K}$ edge. In order to generate the catalyst particle bed one side of the slit was closed with the polycarbonate plate and metal frame. Then a plug of glass wool was inserted in the slit at the exit of the cell, followed by filling in the pre-weighed catalyst. Before closing the entire cell, the particle bed was pressed towards the exit of the cell with a second plug of glass wool. The depth of the slit was defined in a preliminary experiment, where an optical path length of $10 \mathrm{~mm}$ was found to be suitable for transmission measurements with the $\mathrm{X}$-ray beam for the catalytic material $\left(1 \mathrm{wt}-\mathrm{\%} \mathrm{Pd} / \mathrm{TiO}_{2}\right)$ used in this work. The resulting edge step $(\mu)$ was $\sim 0.4$.

Preliminary experiments were initially performed at the synchrotron radiation source to evaluate the influence of reaction conditions on the palladium catalyst and to obtain reference state measurements. Therefore the cell was loaded with $100 \mathrm{mg}$ of the $1 \mathrm{wt} . \% \mathrm{Pd} / \mathrm{TiO}_{2}$ catalyst. First the catalyst bed was scanned by the X-ray beam in a dry state in air under ambient conditions (Exp. nr. 1). The cell was then connected to the reaction stream and the bed was scanned again in a wet state while pumping deionized water with $5 \mathrm{mM} \mathrm{NaBr}$ through the cell at ambient conditions (Exp. nr. 2). For the final preliminary experiment the reaction medium of one vessel was saturated with pure hydrogen at 10 bar and flushed through the cell at 11 bar, providing a reduced reference (Exp. nr. 3).

For the $\mathrm{H}_{2} \mathrm{O}_{2}$ synthesis experiments at the synchrotron radiation source, the reaction medium in the second vessel was saturated with pure oxygen at 10 bars. Both reaction media were then combined in flow before entering the cell. In this set of experiments $25 \mathrm{mg}$ of $1 \mathrm{wt} . \% \mathrm{Pd} / \mathrm{TiO}_{2}$ catalyst was used. Three reactant ratio $\left(\mathrm{H}_{2} / \mathrm{O}_{2}\right)$ regimes were used, labelled as: hydrogen rich (> $2)$, hydrogen lean $(<0.5)$ and balanced $(0.5-2)$ (Exp. nr. 4-7). Afterwards influence of residence time was studied by reducing the liquid flow rate to 0.45 and $0.22 \mathrm{ml} / \mathrm{min}$ (Exp. $\mathrm{nr}$. 8-9).

For all experiments described in the two paragraphs above first an outlet position of the catalyst bed was probed by X-rays until two consecutive identical spectra were recorded. Afterwards a corresponding XAS spectrum was recorded once also at an inlet position.

Following the operando XAS studies, further experiments were performed in the laboratory. The micro gear pumps were replaced with HPLC pumps to increase dosing accuracy at high pressure. Lean, rich and balanced $\mathrm{H}_{2} / \mathrm{O}_{2}$ ratio experiments were then repeated with the in situ cell and exactly the same catalyst bed used for the operando studies, with a flow rate of $1 \mathrm{ml} / \mathrm{min}$ and at 10 bar (Exp. nr. 10). The PEEK tubing connecting the setup and reaction cell was then replaced with stainless steel (Figure S4), to mitigate any effect of partial hydrogen diffusion which may have occurred during operando studies. It should be noted that in the latter case flexible tubing was necessary to avoid hindering the movement of the sample alignment stage motors at the beamline. In the subsequent experiments hydrogen diffusion was also found at the in situ cell, made from a PTFE body and polycarbonate plates using a gas detector. Therefore the $25 \mathrm{mg}$ particle bed was placed in a $6 \mathrm{~mm}$ stainless steel tube to minimize hydrogen diffusion for this experiment (Exp. nr. 11).

Finally, the influence of acid addition was studied, which is known to enhance selectivity in the direct synthesis [3], by adding $1 \mathrm{mM} \mathrm{H}_{2} \mathrm{SO}_{4}$ to the reaction medium in the vessels. The 
experiment was first conducted without acid with a $100 \mathrm{mg}$ catalyst bed in a stainless steel tube with a flow rate of $1.5 \mathrm{ml} / \mathrm{min}$ at 10 bar and was then repeated after acid addition (Exp. nr. 1213).

Table 1: Reaction conditions of the experiments ${ }^{1)}$.

\begin{tabular}{|r|l|r|rrrrr|}
\hline Exp. nr. & Description & $m_{\text {cat. }}, \mathrm{mg}$ & $\dot{V}_{\text {liquid }}{ }^{2}, \mathrm{ml} / \mathrm{min}$ & $c_{\mathrm{H}_{2}}, \mathrm{mmol} / \mathrm{L}$ & $c_{\mathrm{O}_{2}}, \mathrm{mmol} / \mathrm{L}$ & $\mathrm{H}_{2} / \mathrm{O}_{2}{ }^{3}, \mathrm{~mol} / \mathrm{mol}$ & $\mathrm{SV}^{4}, \mathrm{~mol} / \mathrm{g}_{\mathrm{Pd}} / \mathrm{h}$ \\
\hline 1 & ex situ & 100 & - & - & - & - & - \\
\hline 2 & $\mathrm{H}_{2} \mathrm{O}$ flow, wet & 100 & $\sim 1$ & - & - & - \\
\hline 3 & $\mathrm{H}_{2}$ in $\mathrm{H}_{2} \mathrm{O}$ flow & 100 & $\sim 1$ & 8.2 & - & - \\
\hline 4 & hydrogen rich & 25 & 1.2 & $>6$ & $<3$ & 2.49 \\
\hline 5 & balanced & 25 & 1.1 & $4.8-6$ & $4.8-3$ & $1-2$ & $2.53-2.38$ \\
\hline 6 & balanced & 25 & 1 & $3.4-4.8$ & $6.8-4.8$ & $0.5-1$ & $2.45-2.30$ \\
\hline 7 & hydrogen lean & 25 & 1 & $<3.4$ & $>6.8$ & $<0.5$ & 2.45 \\
\hline 8 & hydrogen lean & 25 & 0.45 & $<3.4$ & $>6.8$ & $<0.5$ & 1.1 \\
\hline 9 & hydrogen lean & 25 & 0.22 & $<3.4$ & $>6.8$ & $<0.5$ & 0.54 \\
10 & cell repeated & 25 & 1 & $1.2-6.6$ & $9.9-2.2$ & $0.12-3$ & $2.67-2.12$ \\
11 & steel tube & 25 & 1 & $1.4-6.3$ & $9.6-2.6$ & $0.15-2.4$ & $2.64-2.15$ \\
12 & steel tube & 100 & 1.5 & $1.8-6.3$ & $9-2.6$ & $0.2-2.4$ & $0.98-0.81$ \\
13 & steel tube, acid & 100 & 1.5 & $1.8-5.2$ & $9-4.3$ & $0.2-1.2$ & $0.98-0.85$ \\
\hline
\end{tabular}

1): All experiments were conducted at room temperature under a pressure of 10 bars in the vessels using the 1 wt.- $\% \mathrm{Pd} / \mathrm{TiO}_{2}$ catalyst. Solvents used: $5 \mathrm{mM} \mathrm{NaBr}$ in demineralized water (exp. nr. 1-12); $5 \mathrm{mM} \mathrm{NaBr}$ and $1 \mathrm{mM} \mathrm{H}_{2} \mathrm{SO}_{4}$ in demineralized water (exp. nr. 13). Experiment performed at: synchrotron radiation source (exp. nr. 1-9), laboratory (exp. nr. 10-13); Reactors used: in situ cell (exp. nr. 1-9), steel tube (exp. nr. 10-13).

2): Measured liquid flow rate by weighing the mass collected at the system outlet over time.

3): Estimated molar $\mathrm{H}_{2} / \mathrm{O}_{2}$ ratio based on the saturation concentration of the reactants at 10 bar, the settings of the pumps and the experimental observations.

4): Estimated space velocity, defined as: $S V=\frac{\left(c_{\mathrm{H}_{2}}+c_{\mathrm{O}_{2}}\right) \cdot \text { liquidflow rate }}{\text { mass of Pd in the reaction cell }}$.

The product analysis was performed using an automated system based on a system first described by Pashkova et al. in 2009 [43]. On exiting the reaction cell, the liquid stream was fed after depressurization to an online flow injection analysis system (FIA) to measure the $\mathrm{H}_{2} \mathrm{O}_{2}$ concentration. For this purpose $\mathrm{H}_{2} \mathrm{O}_{2}$ is first contacted with titanium(IV) oxysulfate to form an orange colored complex which is then detected by a UV-Vis spectrometer ("DT-MINI-2-GS" light source with "USB4000-UV-VIS" detector by Ocean Optics) measuring the absorbance at 409 $\mathrm{nm} . \mathrm{H}_{2} \mathrm{O}_{2}$ concentration in the effluent can then be calculated based on a previously determined calibration curve. The product yield $\mathrm{Y}_{\mathrm{H}_{2} \mathrm{O}_{2}}$ was determined by division of the $\mathrm{H}_{2} \mathrm{O}_{2}$ concentration $C_{\mathrm{H}_{2} \mathrm{O}_{2} \text { FIA }}$ by $\mathrm{H}_{2}$ concentration in the feed $c_{\mathrm{H}_{2} \text { feed }}$ (equation 5). The $\mathrm{H}_{2}$ concentration in the feed was calculated by Henry's law, while the partial pressure of $\mathrm{H}_{2}$ was calculated with the pressure 
in the $\mathrm{H}_{2}$ vessel $p_{\mathrm{H}_{2} \text { vessel }}$ multiplied by the flow rate fraction of the $\mathrm{H}_{2}$ pump after mixing with the stream delivered by the $\mathrm{O}_{2}$ pump (equation 6).

$Y_{\mathrm{H}_{2} \mathrm{O}_{2}}=\frac{C_{\mathrm{H}_{2} \mathrm{O}_{2} \text { FIA }}}{c_{\mathrm{H}_{2} \text { feed }}}$
$C_{\mathrm{H}_{2} \text { feed }}=p_{\mathrm{H}_{2} \text { vessel }} \cdot H_{\mathrm{H}_{2}, \mathrm{H}_{2} \mathrm{O}}^{c p} \cdot \frac{\dot{V}_{\mathrm{H}_{2} \text { pump }}}{\dot{V}_{\mathrm{H}_{2} \text { pump }}+\dot{V}_{\mathrm{O}_{2} \text { pump }}}$

With: Henry constant in water $H_{H_{2}, H_{2} O}^{c p}$ (taken from the DETHERM database [44]).

\section{X-ray absorption spectroscopy and data analysis}

X-ray absorption spectra (XANES and EXAFS) at the Pd K absorption edge were recorded at the P65 beamline of PETRA III synchrotron radiation source (DESY, Hamburg) in transmission mode (using ionization chambers as detectors). X-rays were produced by means of an 11 period undulator with a flux of about $10^{11}$ photons/s. Higher harmonics were rejected by a pair of Ptcoated plane mirrors installed in front of the monochromator. The energy of the X-ray photons was further selected by a Si (311) double-crystal monochromator and the beam size was set by means of slits to $1 \times 0.2 \mathrm{~mm}^{2}$. For precise energy calibration a reference spectrum of Pd foil was measured together with each experimental spectrum using an additional ionization chamber located behind the one measuring intensity of the beam transmitted through the in situ cell.

Principal component analysis (PCA) was performed on the full set of measured spectra and identified $\mathrm{Pd}^{0}, \mathrm{PdO}$, and $\mathrm{PdH}_{\mathrm{x}}$ as possible components (see Electronic Supporting Information, section S4, Fig. S6). The average oxidation state of Pd was obtained from X-ray absorption near edge structure (XANES) spectra in the following way. First, the isosbestic points of $\mathrm{Pd}^{0}-\mathrm{PdH}_{\mathrm{x}}$ spectra were identified (Fig. S7b) and it was found that at $24362.5 \mathrm{eV}$ (rising edge region) and at $24390.4 \mathrm{eV}$ (white line region) normalized spectra of $\mathrm{Pd}^{0} / \mathrm{PdH}_{\mathrm{x}}$ had markedly different absorbance when compared to the spectrum of PdO. Since the biggest difference was observed at $24390.4 \mathrm{eV}$ (white line region) normalized absorbance at this energy was used to estimate average fraction of $\mathrm{PdO}$ among $\mathrm{Pd}^{0}, \mathrm{PdO}$, and $\mathrm{PdH}_{\mathrm{x}}$ possible components. The results were in line with variation of an average coordination number of oxygen in the first shell of $\mathrm{Pd}$ obtained from EXAFS fitting. EXAFS fitting was conducted aiming at: 1) estimation of the amount of Pd$\mathrm{Pd}$ nearest neighbors to determine possible changes in $\mathrm{Pd}$ nanoparticle size and oxidation state; 2) estimation of amount of $\mathrm{O}$ atoms in the first shell to evaluate the oxidation state of $\mathrm{Pd}$; 3 ) estimation of average $\mathrm{Pd}-\mathrm{Pd}$ bond distance which can serve as an indicator of hydrogen stored as Pd hydride. The spectra were normalized and the extended X-ray absorption fine structure spectra (EXAFS) background subtracted using the ATHENA program from the IFFEFIT software package [45]. The $k^{1}-, k^{2}$-, and $k^{3}$-weighted EXAFS functions were Fourier transformed in the $k$ range of $3.0-13 \AA^{-1}$ and multiplied by a Hanning window with sill size of $1 \AA^{-1}$. The structural model was based on a Pd metal core (ICSD collection code 52251) and an oxide shell modeled using PdO (ICSD collection code 24692). The structure refinement was performed using ARTEMIS software (IFFEFIT) [45]. For this purpose the corresponding theoretical backscattering amplitudes and phases were calculated by FEFF 6.0 [46]. The theoretical data were then adjusted to the experimental spectra by a least square method in R-space between 1.4 and $3 \AA$. First, the amplitude reduction factor $\left(\mathrm{S}_{0}{ }^{2}=0.8\right)$ was calculated using the $\mathrm{Pd}$ foil reference 
spectrum and then the coordination numbers, interatomic distances, energy shift $\left(\delta \mathrm{E}_{0}\right)$ and mean square deviation of interatomic distances $\left(\sigma^{2}\right)$ were refined. The absolute misfit between theory and experiment was expressed by $\rho$.

\section{Results and discussion}

\section{$\mathrm{H}_{2} \mathrm{O}_{2}$ synthesis experiments}

The $\mathrm{H}_{2} \mathrm{O}_{2}$ ratio was varied across several concentration regimes: hydrogen rich $\left(\mathrm{H}_{2} / \mathrm{O}_{2}>2\right)$, balanced $\left(0.5<\mathrm{H}_{2} / \mathrm{O}_{2}<2\right)$ and hydrogen lean $\left(\mathrm{H}_{2} / \mathrm{O}_{2}<0.5\right)$ for a flow rate of $1 \mathrm{ml} / \mathrm{min}$. $\mathrm{H}_{2} \mathrm{O}_{2}$ was qualitatively detected for balanced $\mathrm{H}_{2} / \mathrm{O}_{2}$ ratios between 0.5 and 2 . The concentration in the outlet stream was estimated to be in the range of $0.03-0.08 \mathrm{mmol} / \mathrm{L}$. In both hydrogen lean and hydrogen rich conditions $\left(\mathrm{H}_{2} / \mathrm{O}_{2}\right.$ ratio $<0.5$ and $>2, \mathrm{H}_{2} \mathrm{O}_{2}$ was below the detection limit. In the latter case this is plausible since too much hydrogen favors the consecutive hydrogenation of the product and parallel water formation. However, if oxygen is present in excess this should not be the case, since product selectivity is expected to increase under O-rich conditions [3]. A reasonable explanation is an insufficient residence time. Hence, we reduced the flow rate to 0.4 $\mathrm{ml} / \mathrm{min}$ and $0.2 \mathrm{ml} / \mathrm{min}$ to increase the residence time for the $\mathrm{H}_{2} / \mathrm{O}_{2}$ ratio $<0.5$. In both cases, $\mathrm{H}_{2} \mathrm{O}_{2}$ was qualitatively detected, although there was no noticeable difference in product concentration. Finally, we optimized the reaction conditions to allow quantitative measurement of $\mathrm{H}_{2} \mathrm{O}_{2}$. Exp. nr. 5 was repeated with increased residence time and a concentration of $0.11 \mathrm{mmol} / \mathrm{L}$ $\mathrm{H}_{2} \mathrm{O}_{2}$ was measured for the $25 \mathrm{mg}$ catalyst bed with a flow rate of $0.8 \mathrm{ml} / \mathrm{min}$ for a $\mathrm{H}_{2} / \mathrm{O}_{2}$ ratio of ca. 1.5 (Figure 2). With a $\mathrm{H}_{2} / \mathrm{O}_{2}$ ratio of 1.5 and Henry's law the product yield with respect to hydrogen can be estimated as $2 \%$. The X-ray spectroscopy results are discussed in the next section.

Following the operando XAS studies, further experiments were performed in the laboratory with a partly modified experimental setup, to further investigate the parameters affecting $\mathrm{H}_{2} \mathrm{O}_{2}$ yield. The results of the following experiments are shown in Figure 2, compared to the operando studies. Initially the experiments with the cell used at the synchrotron radiation source were repeated (Exp. nr. 10). Maximum $\mathrm{H}_{2} \mathrm{O}_{2}$ concentration of $0.1 \mathrm{mmol} / \mathrm{L}$ at a balanced $\mathrm{H}_{2} / \mathrm{O}_{2}$ ratio between 1.2 and 1.8 was measured, which corresponded well with the synchrotron experiments and also the behavior of qualitative product detection of the $\mathrm{H}_{2} / \mathrm{O}_{2}$ ratio variation. In the next step the equipment was optimized to mitigate hydrogen diffusion. Consequently the maximum $\mathrm{H}_{2} \mathrm{O}_{2}$ concentration was tripled to $0.31 \mathrm{mmol} / \mathrm{L}$ and the peak of the variation shifted to a lower $\mathrm{H}_{2} / \mathrm{O}_{2}$ ratio between 0.5 and 1 (Exp. nr. 11). At the highest measured product concentration, the product yield in regard to hydrogen increased to $12 \%$. The space velocity was then reduced to evaluate the influence on conversion (Exp. nr. 12). It was found that the increased residence time did show very similar results over the whole $\mathrm{H}_{2} / \mathrm{O}_{2}$ ratio range in comparison with exp. nr. 11. Very high conversion can therefore be assumed for the limiting reactant. Finally acid was added to the solvent to check for its influence (Exp. nr. 13). A maximum $\mathrm{H}_{2} \mathrm{O}_{2}$ concentration of $0.79 \mathrm{mmol} / \mathrm{L}$ was measured at a $\mathrm{H}_{2} / \mathrm{O}_{2}$ ratio of 0.3 with a product yield in regard to hydrogen of $38 \%$. In conclusion, hydrogen diffusion through the connecting tubes and the in situ cell body was the major cause for the low product yield during XAS experiments. Nevertheless, the 
portable setup design for synchrotron experiments allowed semi-quantitative $\mathrm{H}_{2} \mathrm{O}_{2}$ detection, and thus derivation of structure-activity relationships. A minimal product yield of about $10 \%$ can be assumed for the $1 \mathrm{wt} . \% \mathrm{Pd} / \mathrm{TiO}_{2}$, if the reaction is performed in water with $\mathrm{NaBr}$ at ambient temperature. The product yield can be greatly increased through $\mathrm{H}_{2} \mathrm{SO}_{4}$ addition. However, using an acid causes palladium leaching as proven by ICP metal content analysis of the reactor effluent (ICP results are shown in Table S3 in section S5, SI).

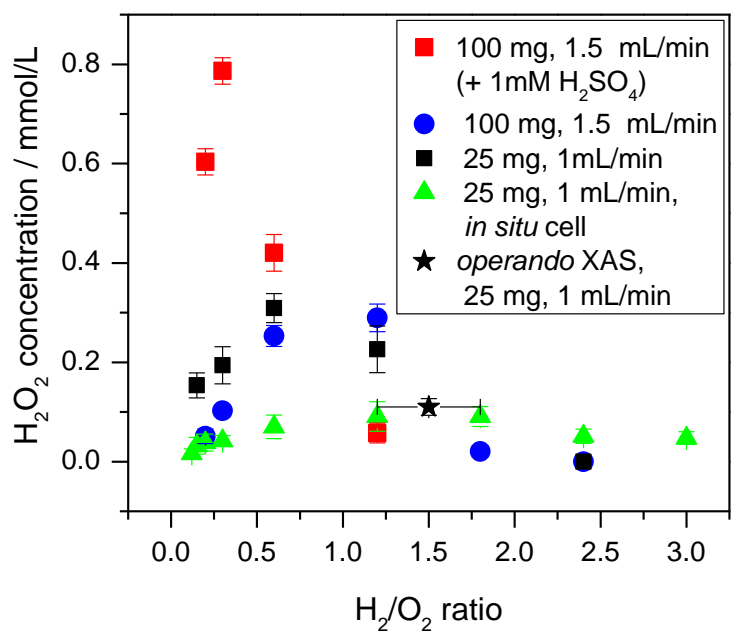

Figure 2. $\mathrm{H}_{2} \mathrm{O}_{2}$ synthesis experiments: single point at DESY (black star) in comparison to laboratory experiments. Error bars for the $\mathrm{H}_{2} \mathrm{O}_{2}$ concentration show standard deviation.

\section{Operando XANES and EXAFS data recorded during direct synthesis of $\mathrm{H}_{2} \mathrm{O}_{2}$}

The full set of experimental XANES spectra plotted together (14 spectra) showed no isosbestic points (i.e. the points at which the spectra of two substances intersect, thus showing the same absorbance) which means that they could not be regarded as a combination of spectra of just two species, more components should be taken into account. This situation differs from the observations in literature [37] where linear combination analysis (LCA) of $\mathrm{PdO}$ and $\mathrm{Pd}^{0}$ spectra was enough to model experimental data and obtain the average oxidation state of $\mathrm{Pd}$. This initially highlights the importance of performing spectroscopic measurements until realistic process conditions, in this case at high partial pressure of reactants and in continuous flow. In our case in order to identify the number of required components and their nature a PCA was performed (for more details cf. SI). The results of the PCA suggested that taking into account three components was enough to describe the obtained set of XANES spectra with sufficient precision, and these components are probably $\mathrm{Pd}^{0}, \mathrm{PdO}$ and $\mathrm{Pd}$ hydride $\left(\mathrm{PdH}_{\mathrm{x}}\right.$ [47]). Therefore Figure 3 shows XANES and EXAFS spectra of Pd foil (Goodfellow), PdO (CAS Nr. 1314-08-5, Chempur), and 1 wt.- $\% \mathrm{Pd} / \mathrm{TiO}_{2}$ catalyst in $\mathrm{H}_{2} / \mathrm{H}_{2} \mathrm{O}$ flow (the spectra of which correspond to $\beta$ $\mathrm{PdH}_{\mathrm{x}}$ phase [47-50]) which were further used as references for XANES and EXAFS analysis. Although PCA helped to identify the relevant palladium species, it cannot be used for quantification as it does not directly provide physically meaningful spectra. Due to the high similarity between the XANES spectra of $\mathrm{Pd}^{0}$ and $\mathrm{PdH}_{\mathrm{x}}$, LCA could also not provide reliable results. Therefore, a different strategy to estimate the oxidation state was employed: first, 
isosbestic points of $\mathrm{Pd}^{0}-\mathrm{Pd}$ hydride mixture were identified (Figure 4) and it was found that at $24362.5 \mathrm{eV}$ (rising edge region) and at $24390.4 \mathrm{eV}$ (white line region) normalized spectra of $\mathrm{Pd} / \mathrm{PdH}_{\mathrm{x}}$ have markedly different absorbance when compared to the spectrum of $\mathrm{PdO}$. Since the biggest difference was observed at $24390.4 \mathrm{eV}$ (white line region) we used the normalized absorbance at this energy to estimate the average fraction of $\mathrm{PdO}$ in the spectra and, thus, average oxidation state of $\mathrm{Pd}$. EXAFS fitting parameters for all reference materials and operando experiments performed together with their relevant reaction conditions are outlined in Table 2, exemplary fits are reported in the SI (Fig. S8).

Table 2: Summary of EXAFS fitting results of selected experimental spectra.

\begin{tabular}{|c|c|c|c|c|c|c|c|c|c|}
\hline Exp. nr. & Description & $\begin{array}{l}\mathrm{cH}_{2} \mathrm{O}_{2} \\
\mathrm{mmol} / \mathrm{L}\end{array}$ & $\mathrm{d}(\mathrm{Pd}-\mathrm{O}), \AA$ & $\mathrm{CN}(\mathrm{O})$ & $\mathrm{d}(\mathrm{Pd}-\mathrm{Pd}), \AA$ & $\mathrm{CN}(\mathrm{Pd})$ & $\begin{array}{l}\sigma^{2}\left(10^{-3}\right. \\
\left.\AA^{2}\right)\end{array}$ & $\delta \mathrm{E}_{0}(\mathrm{eV})$ & $\rho(\%)$ \\
\hline- & $P d$ foil $^{1}$ & & n.a. & n.a. & $2.74 \pm 0.003$ & 12 & $4.7 \pm 0.6$ & $1.3 \pm 0.7$ & 1.1 \\
\hline- & $\mathrm{PdO}$ tetragonal ${ }^{2}$ & & 2.02 & 4 & 3.03 & 4 & & & \\
\hline- & $\mathrm{PdO}$ hexagonal ${ }^{2}$ & & 2.02 & 4 & 3.42 & 8 & & & \\
\hline 1 & ex situ & & $1.98 \pm 0.02$ & $2.6 \pm 0.4$ & $2.73 \pm 0.01$ & $5 \pm 1.0$ & $6.6 \pm 1.4$ & $1.2 \pm 1.5$ & 2.4 \\
\hline 2 & $\mathrm{H}_{2} \mathrm{O}$ flow, wet & & $1.97 \pm 0.02$ & $2.2 \pm 0.4$ & $2.74 \pm 0.01$ & $5.3 \pm 1.1$ & $6.3 \pm 1.4$ & $2.1 \pm 1.5$ & 2.4 \\
\hline 3 & $\mathrm{H}_{2}$ in $\mathrm{H}_{2} \mathrm{O}$ flow & & $1.99 \pm 0.1$ & $0.4 \pm 0.4$ & $2.814 \pm 0.005$ & $10.3 \pm 1.0$ & $7.7 \pm 0.7$ & $-0.2 \pm 0.6$ & 0.7 \\
\hline 4 outlet & $\mathrm{H}_{2} / \mathrm{O}_{2}>2,1.2 \mathrm{ml} / \mathrm{min}$ & $\sim 0$ & n.a. & 0 & $2.815 \pm 0.005$ & $9.2 \pm 0.9$ & $6.9 \pm 0.6$ & $0.0 \pm 0.6$ & 0.6 \\
\hline 5 outlet & & $0.05-0.08$ & $1.97 \pm 0.03$ & $1.1 \pm 0.4$ & $2.733 \pm 0.007$ & $7.2 \pm 1.0$ & $6.2 \pm 0.9$ & $0.2 \pm 1.0$ & 1.1 \\
\hline 5 inlet & $\mathrm{H}_{2} / \mathrm{O}_{2} 1-2,1.1 \mathrm{ml} / \mathrm{min}$ & $0.05-0.08$ & $1.98 \pm 0.04$ & $0.9 \pm 0.4$ & $2.734 \pm 0.004$ & $7.8 \pm 0.9$ & $6.0 \pm 0.7$ & $0.3 \pm 0.8$ & 0.7 \\
\hline 6 outlet & & $0.05-0.08$ & $1.97 \pm 0.02$ & $1.5 \pm 0.4$ & $2.736 \pm 0.005$ & $7.5 \pm 0.8$ & $6.8 \pm 0.7$ & $0.3 \pm 0.8$ & 1.0 \\
\hline 6 inlet & $\mathrm{H}_{2} / \mathrm{O}_{2} 0.5-1,1 \mathrm{ml} / \mathrm{min}$ & $0.05-0.08$ & $1.98 \pm 0.05$ & $1.0 \pm 0.5$ & $2.736 \pm 0.006$ & $7.9 \pm 1.2$ & $6.5 \pm 1.0$ & $0.7 \pm 1.0$ & 1.5 \\
\hline 7 outlet & & $\sim 0$ & $1.97 \pm 0.02$ & $1.6 \pm 0.4$ & $2.731 \pm 0.007$ & $7.0 \pm 1.0$ & $6.0 \pm 0.8$ & $0.0 \pm 1.0$ & 1.3 \\
\hline 7 inlet & $\mathrm{H}_{2} / \mathrm{O}_{2}<0.5,1 \mathrm{ml} / \mathrm{min}$ & $\sim 0$ & $1.99 \pm 0.03$ & $1.1 \pm 0.3$ & $2.733 \pm 0.005$ & $7.4 \pm 0.8$ & $6.0 \pm 0.7$ & $0.4 \pm 0.8$ & 0.8 \\
\hline 8 outlet & $\mathrm{H}_{2} / \mathrm{O}_{2}<0.5,0.45$ & qualitative & $1.97 \pm 0.02$ & $1.5 \pm 0.4$ & $2.738 \pm 0.006$ & $6.9 \pm 0.9$ & $6.2 \pm 0.9$ & $0.5 \pm 1.0$ & 1.2 \\
\hline 8 inlet & $\mathrm{ml} / \mathrm{min}$ & qualitative & $1.98 \pm 0.04$ & $1.2 \pm 0.4$ & $2.735 \pm 0.006$ & $7.4 \pm 1.0$ & $6.0 \pm 0.9$ & $0.4 \pm 1.0$ & 1.3 \\
\hline 9 outlet & $\mathrm{H}_{2} / \mathrm{O}_{2}<0.5,0.22$ & qualitative & $1.98 \pm 0.02$ & $1.6 \pm 0.4$ & $2.735 \pm 0.007$ & $6.6 \pm 0.9$ & $5.7 \pm 0.8$ & $0.3 \pm 1.0$ & 1.2 \\
\hline 9 inlet & $\mathrm{ml} / \mathrm{min}$ & qualitative & $1.98 \pm 0.04$ & $1.3 \pm 0.6$ & $2.736 \pm 0.007$ & $8.3 \pm 1.3$ & $6.7 \pm 1.1$ & $0.8 \pm 1.2$ & 1.5 \\
\hline
\end{tabular}

1: Pd model from the ICSD database (collection code 52251) was used for the fit.

2: Values taken from [51]. 

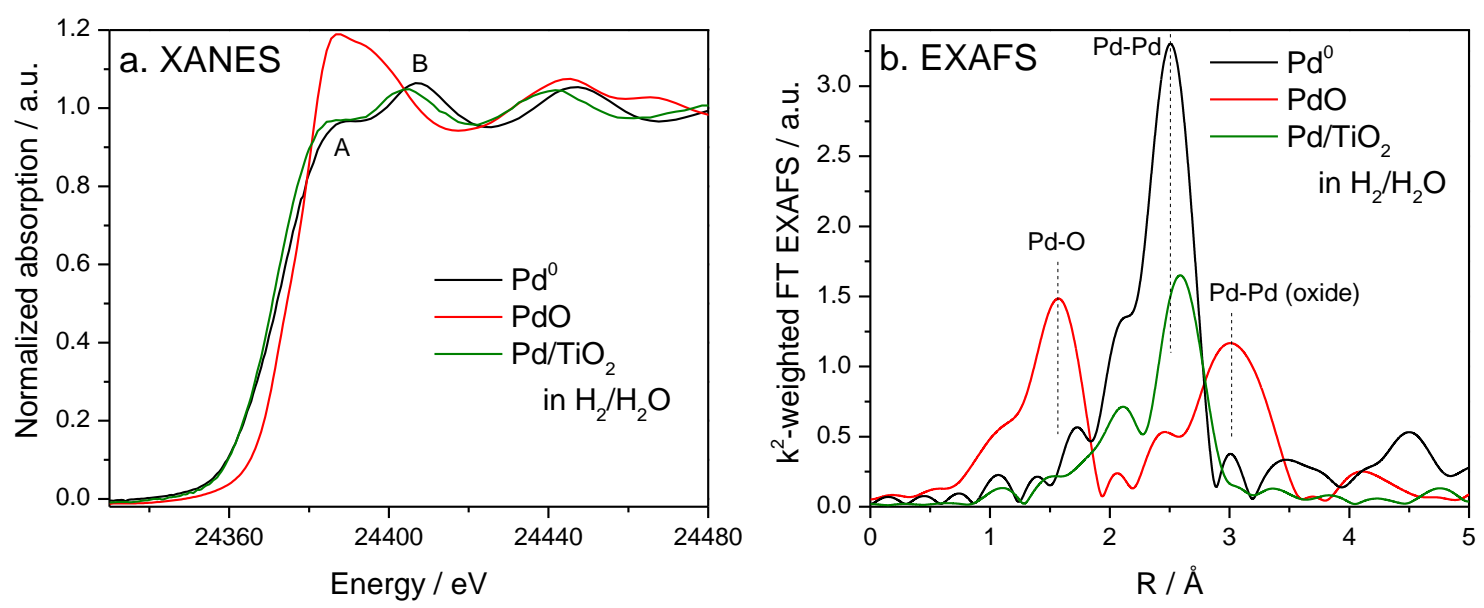

Figure 3. (a) XANES and (b) FT k ${ }^{2}$-weighted EXAFS spectra (not corrected for phase shift) of reference compounds $\mathrm{Pd}^{0}$ ( $\mathrm{Pd}$ foil), $\mathrm{PdO}$, and $\beta-\mathrm{PdH}_{\mathrm{x}}\left(\mathrm{Pd} / \mathrm{TiO}_{2}\right.$ catalyst in $\mathrm{H}_{2} / \mathrm{H}_{2} \mathrm{O}$ medium).
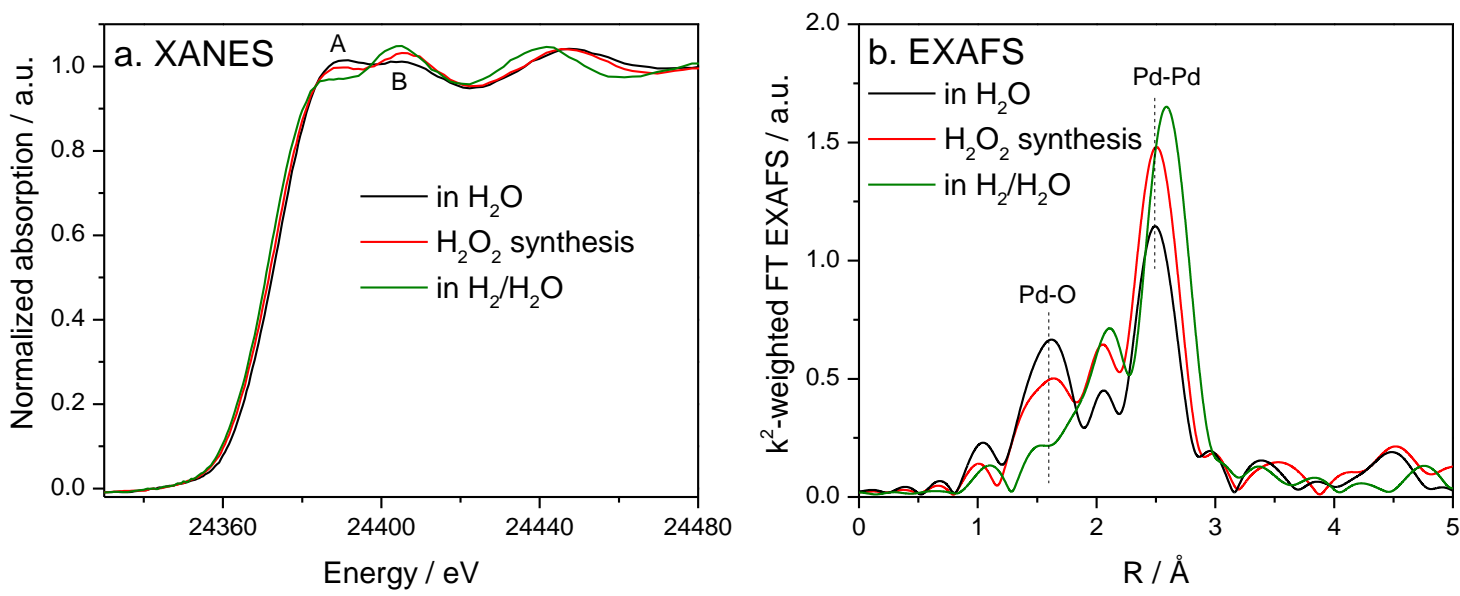

Figure 4. (a) XANES and (b) FT k ${ }^{2}$-weighted EXAFS (not corrected for the phase shift) spectra of $\mathrm{Pd} / \mathrm{TiO}_{2}$ catalyst in $\mathrm{H}_{2} \mathrm{O}$, in $\mathrm{H}_{2} / \mathrm{H}_{2} \mathrm{O}$, and under balanced $\mathrm{H}_{2} \mathrm{O}_{2}$ synthesis conditions $\left(\mathrm{H}_{2}: \mathrm{O}_{2}\right.$ ratio = $0.5-1$, exp. nr. 6, outlet).

Figure 4 displays XAS spectra of the $\mathrm{Pd} / \mathrm{TiO}_{2}$ catalyst under flow of $\mathrm{H}_{2} \mathrm{O}$ (not degassed, i.e. saturated with $\mathrm{O}_{2}$ from ambient air), under $\mathrm{H}_{2} \mathrm{O}_{2}$ synthesis conditions (mixture of flows saturated by $\mathrm{H}_{2}$ and $\mathrm{O}_{2}$ at 9 bar (Exp. nr. 6, Table 2), and under $\mathrm{H}_{2}$-saturated water. Under balanced conditions $\left(\mathrm{H}_{2} / \mathrm{O}_{2}\right.$ ratio 0.5-1) $\mathrm{H}_{2} \mathrm{O}_{2}$ formation was observed during the corresponding experiment (Table 2), and the spectral features lie between the spectra of $\mathrm{Pd} / \mathrm{TiO}_{2}$ obtained in water or $\mathrm{H}_{2} / \mathrm{H}_{2} \mathrm{O}$ flows. Evidently, $\mathrm{Pd}$ is present in the form of predominantly metallic nanoparticles which show some contribution from oxygen, visible as an increase in intensity of XANES white line (peak A) and backscattering at $1.6 \AA$ (uncorrected for the phase shift) in EXAFS spectra. Figure 5a shows the $\mathrm{PdO}$ fraction for the $\mathrm{H}_{2} / \mathrm{O}_{2}$ ratio variation (Exp. 4-6, Table 2) and the residence 
time variation (Exp. 7-9, Table 2) in comparison to the reference experiments. The ex situ sample and the wet sample both contained a PdO fraction of roughly $22 \%$, while the wet sample was slightly less oxidized. In contrast, the sample flushed with hydrogen dissolved in water was almost fully reduced with a $\mathrm{PdO}$ fraction below $2 \%$. The same reduced state was observed during $\mathrm{H}_{2} \mathrm{O}_{2}$ synthesis under hydrogen rich conditions $\left(\mathrm{H}_{2} / \mathrm{O}_{2}\right.$ ratio $\left.>2\right)$. This can be explained according to the stoichiometry of water formation, if the $\mathrm{H}_{2} / \mathrm{O}_{2}$ ratio exceeds this limit all oxygen in the feed can react to water and the excess hydrogen can then reduce the palladium over time. All other reaction experiments with $\mathrm{H}_{2} / \mathrm{O}_{2}$ ratios below 2 did show an average $\mathrm{PdO}$ fraction of about $15 \%$ at the outlet and a fraction of $10 \%$ at the inlet of the catalyst bed. The oxidation state of the active catalyst (balanced $\mathrm{H}_{2} / \mathrm{O}_{2}$ ratio between $0.5-2$ ) is therefore between a fully reduced state and a partially oxidized state of the ex situ sample. The ex situ sample was most likely partially oxidized by oxygen present in the atmosphere as it was not rendered inert by any reductive pretreatment at high temperature. Furthermore, the inlet of the catalyst bed was always more reduced than the outlet (Figure 5). Hence, more hydrogen was consumed than oxygen, which shows the favored water formation and is consistent with the low $\mathrm{H}_{2} \mathrm{O}_{2}$ yield observed during XAS studies. In addition, the clearly visible hydrogen consumption leads to the conclusion that the reaction was not only influenced by the $\mathrm{H}_{2} / \mathrm{O}_{2}$ ratio in the feed but it was also influenced by the change of the $\mathrm{H}_{2} / \mathrm{O}_{2}$ ratio along the catalyst bed (i.e. a gradient of $\mathrm{H}_{2} / \mathrm{O}_{2}$ ratio along the catalyst bed occurred). The trend of $\mathrm{PdO}$ fraction extracted from the XANES (Figure 5a) spectra was in line with the average coordination number of oxygen in the first shell of $\mathrm{Pd}$ obtained from EXAFS analysis (Figure $5 b$ ).
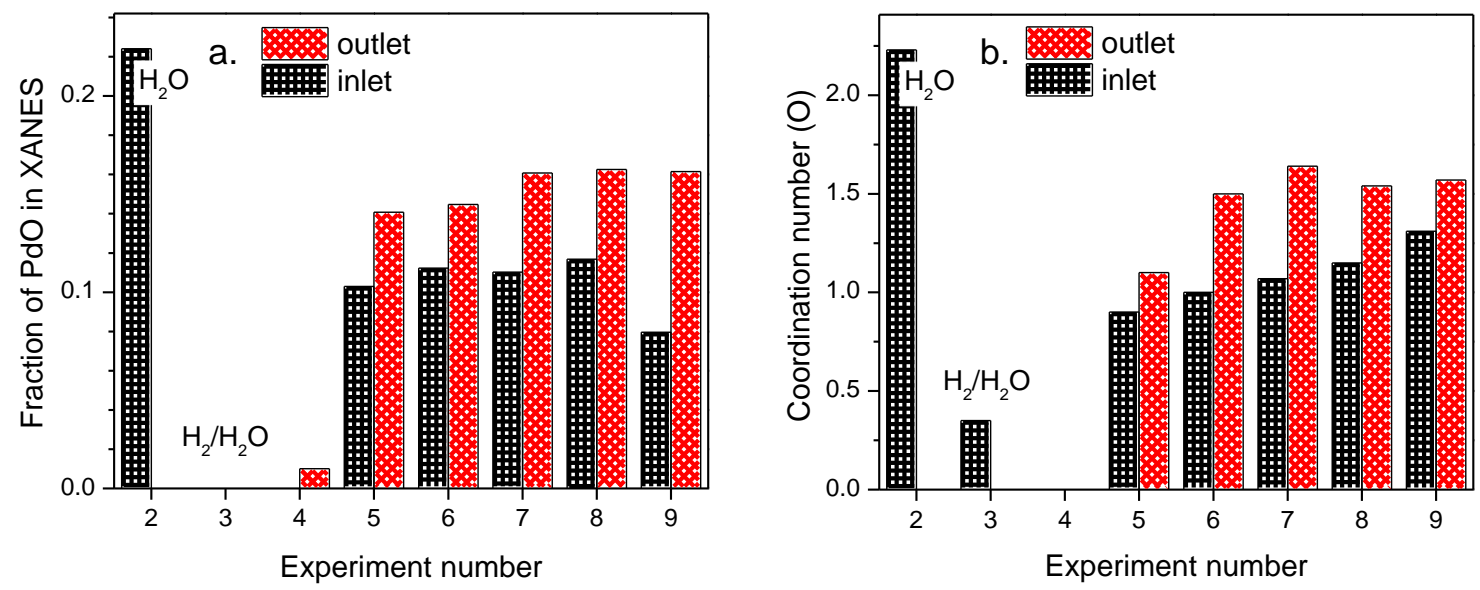

Figure 5. (a) PdO fraction obtained from XANES analysis and (b) average coordination number of Pt with respect to the O-backscatterer from EXAFS fitting.

Usually, the formation and stoichiometry of Pd hydride is identified from the increase in Pd-Pd bond distances, e.g. extracted from the EXAFS or XRD [48,52], from the relative intensity of the first two peaks in the XANES at $24390.5 \mathrm{eV}$ and $24406.6 \mathrm{eV}$, called peaks A and B (Figure 3a and $4 \mathrm{a}$, lower $\mathrm{A} / \mathrm{B}$ ratio is a signature of $\mathrm{PdH}_{\mathrm{x}}$ ), and also from the shift of the peak $\mathrm{B}$ (to lower 
energy for $\mathrm{PdH}_{\mathrm{x}}$, cf. Figure 6) [47]. The sample flushed with $\mathrm{H}_{2}$ dissolved in water, the $\mathrm{Pd}$ foil and the experiment under hydrogen rich conditions $\left(\mathrm{H}_{2} / \mathrm{O}_{2}\right.$ ratio $\left.>2\right)$ showed the smallest values for the A/B peak ratio from the XANES (Figure 7). The highest values were calculated for the ex situ sample and the wet sample flushed with water. The peak ratios of all other reaction experiments, including hydrogen lean and balanced conditions, were between these extremes. Due to the similarity to the results for the $\mathrm{PdO}$ fraction, the $\mathrm{A} / \mathrm{B}$ peak ratio is possibly strongly influenced by the degree of reduction. Since $A / B$ ratio is also influenced by the oxidation state, although a qualitative trend (Figure 7a) is in line with possible $\mathrm{Pd}$ hydride formation at higher $\mathrm{H}_{2} / \mathrm{O}_{2}$ ratios, it alone could not serve as a proof of $\mathrm{PdH}_{\mathrm{x}}$ formation. The same applies to the increase in $\mathrm{Pd}-\mathrm{Pd}$ bond distance which was always within error bars $(<0.01 \AA$, cf. Table 2$)$ unless the catalyst was exposed to the excess of $\mathrm{H}_{2}$. The two exclusions however showed a significantly increased Pd$\mathrm{Pd}$ bond of about $2.81 \AA$ compared to $2.73 \AA$ in other cases. We should note that the changes from $\mathrm{Pd}^{0}$ which lie within error bars are typically observed for an $\alpha-\mathrm{PdH}_{\mathrm{x}}$ phase [47].

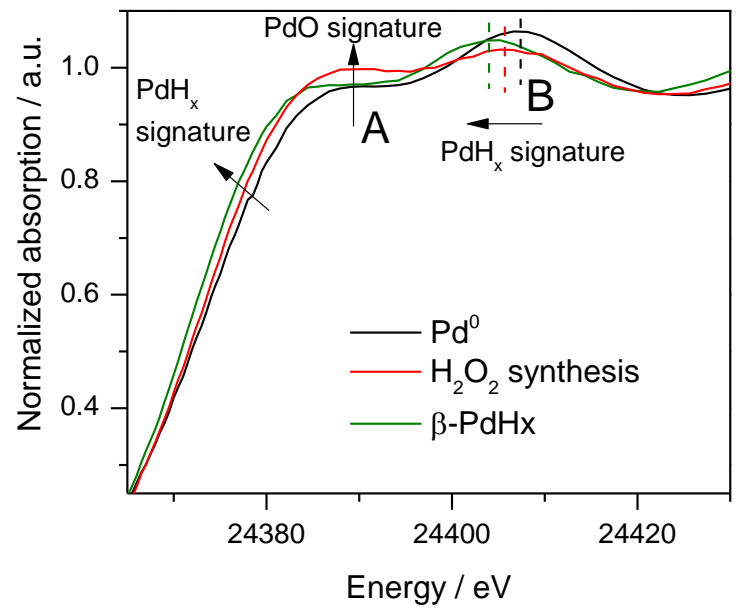

Figure 6. XANES spectra of the active $\mathrm{Pd}$ catalyst $\left(\mathrm{H}_{2} / \mathrm{O}_{2}\right.$ ratio of $0.5-1$, exp. 6 , outlet $)$ as well as $\mathrm{Pd}^{0}$ and $\beta-\mathrm{PdH}_{\mathrm{x}}$ references.

$\alpha-\mathrm{PdH}_{\mathrm{x}}$ is present as long as free space in the lattice can be occupied by hydrogen without swelling [47]. Formation of $\beta-\mathrm{PdH}_{\mathrm{x}}$ phase occurs, when hydrogen needs more space than available and therefore the lattice has to change through isotropic expansion [53,54]. At a Pd-Pd distance of $2.81 \AA \beta-\mathrm{PdH}_{\mathrm{x}}$ phase formation is completed and further hydrogen uptake is not possible, as measured under hydrogen rich and $\mathrm{H}_{2} / \mathrm{H}_{2} \mathrm{O}$ conditions. In contrast, all other experiments showed no indication for $\beta-\mathrm{PdH}_{\mathrm{x}}$ formation due to a $\mathrm{Pd}-\mathrm{Pd}$ bond length similar to pure Pd. However, the number of Pd neighbors in the first coordination shell increased from 5 for the ex situ sample to 6-8 for the reaction experiments (hydrogen lean and balanced $\mathrm{H}_{2} \mathrm{O}_{2}$ ratios) to 9-10 for the experiments with excess hydrogen. The increase in Pd-Pd coordination number upon hydrogen sorption was observed previously [55] (reporting the same coordination numbers and also an increase from 7.5 (2.5 nm Pd NPs) to 9.0 (hydride PdHx) in the gas phase, i.e. without possibility to lose $\mathrm{Pd}^{2+}$ in solution. In our case the increase in $\mathrm{Pd}-\mathrm{Pd}$ coordination number 
may also be attributed to reduction (which we see as decrease in Pd-O coordination number and also in the intensity of the peak $\mathrm{A}$ in XANES, Fig. 6), thus, as reaction conditions change $\mathrm{Pd}$ particles may undergo shape change or redispersion and particle growth as a result of exposure to more oxidizing or more reducing flows. Indeed, exactly the morphological variation from a flat toward a hemispherical particle shape was held responsible for reversible variations of Pd-Pd coordination numbers upon reduction and reoxidation of $\mathrm{Pd}$ nanoparticles by $\mathrm{M}$. Newton et al. [56]. Zlotea et al. [55] based on in situ XRD results proposed that hydrogen absorption causes structural transformation of $\mathrm{Pd}$ nanoparticles from cuboctahedral to icosahedral symmetry. Cuboctahedron is enclosed by $\{100\}$ and $\{111\}$ surfaces where Pd atoms have eight and nine nearest neighbors, respectively, while icosahedrons is capped by $\{111\}$ surface which increases the average Pd-Pd coordination number in the new structure.

Theoretically a combination of $10-15 \%$ of single $\mathrm{Pd}^{2+}$ complexes in the liquid phase and completely O-free $\mathrm{PdHx}$ nanoparticles may also explain the observed average oxidation state of $\mathrm{Pd}$, however, a coincidence of the measured average $\mathrm{Pd}$ oxidation state with the one based on the assumption of surface oxygen is unlikely. No leaching of $\mathrm{Pd}^{2+}$ in the liquid phase is further supported by the fact that Pd was not detected in the effluent after tests and that the total height of the $\mathrm{Pd} \mathrm{K} \mathrm{X-ray} \mathrm{absorption} \mathrm{edge} \mathrm{in} \mathrm{the} \mathrm{XANES} \mathrm{spectra} \mathrm{remained} \mathrm{unchanged} \mathrm{(prior} \mathrm{to}$ normalization, not shown).

In comparison to pure palladium oxide (3 $\AA$ [51]) and the experiments with excess $\mathrm{H}_{2}$ the $\mathrm{Pd}-\mathrm{Pd}$ distance is smaller for the reaction experiments, which means lattice oxygen is highly unlikely during reaction, since a Pd-Pd bond increase [35] was not observed for the hydrogen lean condition $\left(\mathrm{H}_{2} / \mathrm{O}_{2}\right.$ ratio $\left.<0.5\right)$ or the as prepared sample. Subsequent STEM analysis (see $\mathrm{SI}$ Figures S2-S3) showed that the calcined catalyst had sub-nanometer sized Pd particles. After reduction, the particle size increased to an average of about $2.8+/-1.5 \mathrm{~nm}$, and Pd particles were clearly visible. STEM analysis of the catalyst following $\mathrm{H}_{2} \mathrm{O}_{2}$ synthesis experiments at the synchrotron radiation source showed a reduction in particle size to $2.1+/-1.2 \mathrm{~nm}$ together with a lower size distribution. This effect correlates with the findings in the EXAFS as stated above, with the apparent increase in $\mathrm{Pd}-\mathrm{Pd}$ coordination number during reaction due to restructuring of the Pd NPs. The icosahedron formation leads to an increased density, hence decreased volume. $\mathrm{Pd}$ leaching was excluded by metal content analysis and constant height of $\mathrm{Pd} \mathrm{K} \mathrm{X-ray}$ absorption edge.

During the study it was noticed that with higher $\mathrm{H}_{2}$ content and the consequent reduction of $\mathrm{Pd}$ (Exp 1-3, Table 2) the Debye-Waller factor $\sigma^{2}$ also increased (Table 2). Increase in the DebyeWaller factor in $\mathrm{Pd}-\mathrm{H}_{2}$ systems was also observed in $[48,53,55,57]$ and ascribed to inhomogeneous $\mathrm{H}$ distribution in $\mathrm{Pd}$ nanoparticles (more $\mathrm{H}$, therefore, higher distortion in the shell and $\mathrm{H}$-free $\mathrm{Pd}$ core) resulting in broader distribution of $\mathrm{Pd}-\mathrm{Pd}$ interatomic distances. Thus, the increased Debye-Waller factor supports observation of $\mathrm{PdH}_{\mathrm{x}}$ during $\mathrm{H}_{2} \mathrm{O}_{2}$ synthesis.

Another indication of $\mathrm{Pd}$ hydride formation is a shift of the rising edge or $\mathrm{E}_{0}$ (defined as the inflection point on the rising edge or maximum of the first derivative) in the XAS spectra. Oxidation of $\mathrm{Pd}$ shifts rising edge and $\mathrm{E}_{0}$ to higher energy (Figure $3 \mathrm{a}$ ) while the rising edge in the $\mathrm{PdH}_{\mathrm{x}}$ spectrum here was shifted to lower energies (Figure 6). Figure $7 \mathrm{~b}$ summarizes the position of the rising edge in the obtained XANES spectra at a normalized absorbance 0.815 (isosbestic 
point of $\mathrm{Pd}^{0}$ and $\mathrm{PdO}$ ) and unlike the $\mathrm{A} / \mathrm{B}$ ratio, this value was not influenced by partial oxidation of $\mathrm{Pd}$. Clearly, under $\mathrm{H}_{2}$ excess conditions a strong shift of the rising edge to lower energies is observed, the same applies for all measurements at the outlet positions made during $\mathrm{H}_{2} \mathrm{O}_{2}$ synthesis. Interestingly, these data suggest higher fraction of $\mathrm{Pd}$ hydride at the outlet of the catalyst which is in contradiction to the observations of $A / B$ peak ratio. Here we should once again consider that $\mathrm{A} / \mathrm{B}$ peak ratio is influenced by both hydride fraction and $\mathrm{PdO}$ fraction, therefore we believe that the trend of the rising edge position should be followed when estimating $\mathrm{H}$ content in the $\mathrm{Pd}$ hydride. This brings an unexpected observation that the outlet zone of the catalyst bed is characterized by both higher $\mathrm{Pd}$ hydride fraction and slightly higher $\mathrm{O}$ content than in the inlet. One possible explanation is that ensembles of $\mathrm{O}$ and $\mathrm{H}$ atoms are needed for reaction, so that at lower partial pressures $\mathrm{O}$ and $\mathrm{H}$ atoms still sit on/in $\mathrm{Pd}$ but do not react.
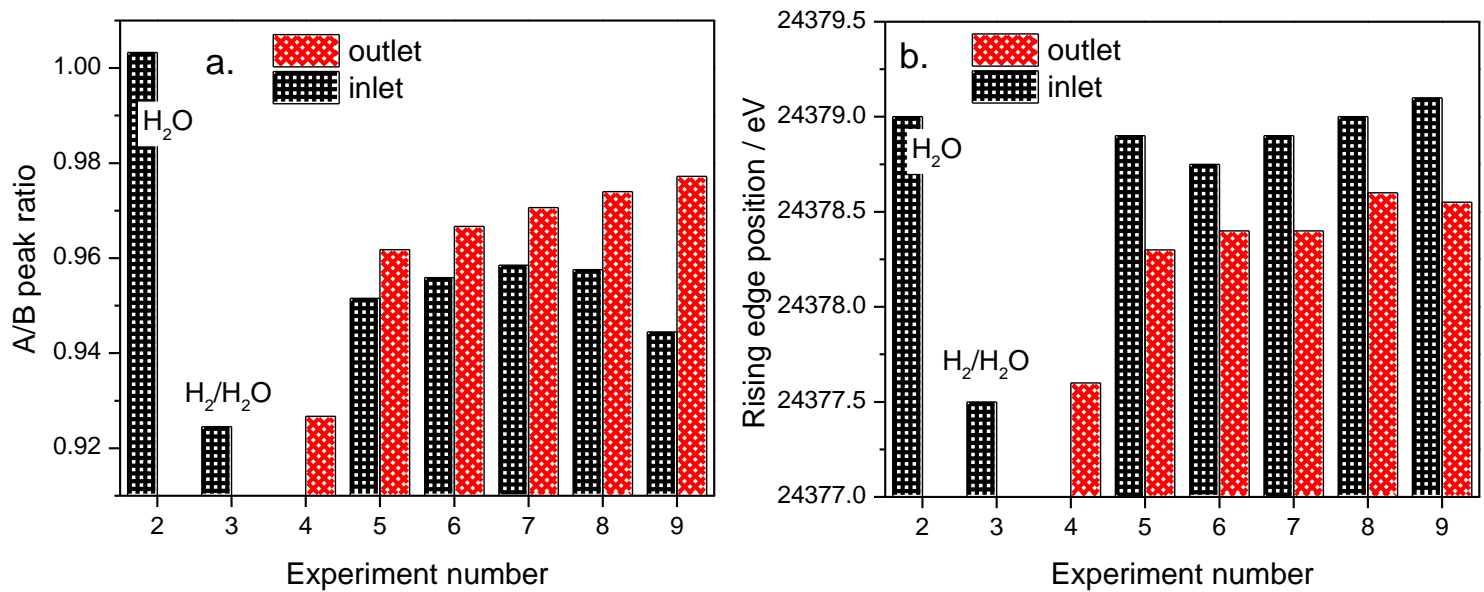

Figure 7. (a) A/B peak ratio and (b) position of the rising edge at normalized absorbance 0.815 in the XANES spectra of $\mathrm{Pd} / \mathrm{TiO}_{2}$ under $\mathrm{H}_{2} \mathrm{O}_{2}$ synthesis and reference conditions.

\section{Reaction mechanism}

A tentative reaction mechanism for the direct synthesis of $\mathrm{H}_{2} \mathrm{O}_{2}$ at high pressure in continuous flow is shown in Figure 8. During $\mathrm{H}_{2} \mathrm{O}_{2}$ synthesis experiments oxygen was clearly present on the palladium surface and was not incorporated in the lattice. Furthermore, hydrogen was found to be dissolved in palladium in the form of $\alpha-\mathrm{PdH}_{\mathrm{x}}$ during hydrogen peroxide formation (balanced $\mathrm{H}_{2} / \mathrm{O}_{2}$ ratio) (Figure 8, bottom arrow). In contrast, $ß-\mathrm{PdH}_{\mathrm{x}}$ formation was observed with excess hydrogen where no $\mathrm{H}_{2} \mathrm{O}_{2}$ was detected (Figure 8, top arrows). From the literature, in both $\mathrm{PdH}_{\mathrm{x}}$ phases hydrogen occupies octahedral sites in the Pd lattice in a dissolved state in single atom form, which can be considered as an activated state [58]. Hence, this work is an experimental indication that lattice hydrogen plays a crucial role in the reaction network of direct synthesis of hydrogen peroxide on metallic palladium, while oxygen is only reacting from the palladium surface. This is in line with the suggestion of the literature that subsurface hydrogen is important 
for the performance of the reaction [12-14]. Furthermore it is an alternate explanation for the observation of Wilson and Flaherty [30] that a Langmuir-Hinshelwood mechanism is unable to describe the direct synthesis reaction. Hence, besides catalyst surface also shape, volume and dissolution kinetics have to be taken into account for the reaction mechanism as a consequence of these findings.
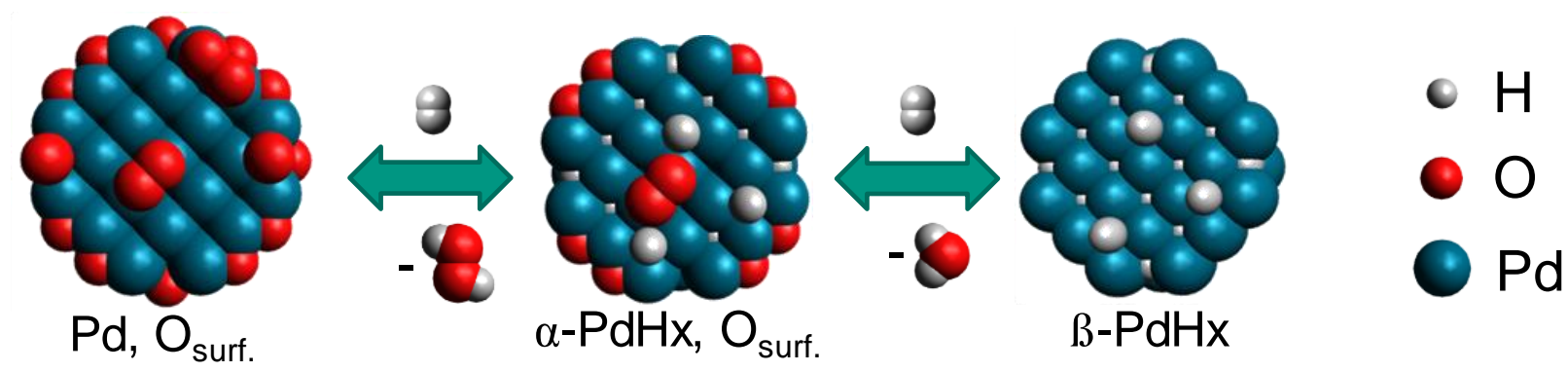

Figure 8. Schematic representation of the structure of $\mathrm{Pd}$ nanoparticles at different stages of direct $\mathrm{H}_{2} \mathrm{O}_{2}$ synthesis as observed by operando XAS.

In regards to product selectivity, it is often observed that $\mathrm{H}_{2} / \mathrm{O}_{2}$ ratios with excess oxygen show increased selectivity to $\mathrm{H}_{2} \mathrm{O}_{2}$. On the one hand, this is due to the stoichiometry of the reaction, on the other hand, oxygen adsorption is favored on the palladium surface [58]. Hence, the amount of surface hydrogen is lowered (if sites are shared) or the adsorption is slowed down. Furthermore, hydrogen dissolution in the Pd lattice might be hindered as well as also suggested by $[12,13]$ that impurities enhance selectivity by limiting hydrogen uptake. Both could cause a positive effect on the selectivity by slowing down the overall reaction and thereby limiting the hydrogenation of $\mathrm{H}_{2} \mathrm{O}_{2}$ to water. This could be explained by a reduced total amount and mobility of hydrogen in partially oxidized palladium lattices as mentioned by Like et al. [10]. Furthermore, unreactive surface oxygen effectively lowers the number of available catalyst surface sites. However, if the lattice is fully oxidized to $\mathrm{PdO}$ the reaction cannot take place via lattice hydrogen at all and the reaction can only take place via surface hydrogen or $\mathrm{H}^{+}$dissolved in the solvent. A similar behavior was experimentally found by operando studies for $\mathrm{Pd}$ catalyzed alkyne hydrogenation [59]. In this case selective hydrogenation was only possible after decoupling of surface and bulk events of palladium. In the end, the main question that evolves is which of the possible active forms of hydrogen favors $\mathrm{H}_{2} \mathrm{O}_{2}$ formation? Lattice hydrogen dissolved in palladium, surface hydrogen adsorbed on the catalyst surface or protic $\mathrm{H}^{+}$dissolved in the solvent? A definitive answer to this question will be integral to the design of future catalysts to promote the highest efficiency and selectivity for this valuable chemical process.

\section{Conclusions}

This work constitutes the first operando XAS study of $\mathrm{H}_{2} \mathrm{O}_{2}$ direct synthesis performed in continuous flow at elevated pressures. The experiments were able to reveal as yet unknown insights into the reaction mechanism of the direct synthesis reaction by combining catalytic performance measurements with operando XAS. XANES and EXAFS observed Pd nanoparticles with a metallic core. Under reaction conditions chemisorbed oxygen was found on the catalyst surface, while hydrogen dissolved in the Pd lattice was deduced from the formation 
of palladium hydride. For $\mathrm{H}_{2} / \mathrm{O}_{2}$ ratios $<2 \alpha-\mathrm{PdH}_{\mathrm{x}}$ was suspected, for $\mathrm{H}_{2} / \mathrm{O}_{2}$ ratio $>2 ß-\mathrm{PdH}_{\mathrm{x}}$. $\mathrm{H}_{2} \mathrm{O}_{2}$ was only detected together with $\alpha-\mathrm{PdH}_{\mathrm{x}}$, which corresponds to $\mathrm{H}_{2} / \mathrm{O}_{2}$ ratios from 0 to 2 being reasonable for $\mathrm{H}_{2} \mathrm{O}_{2}$ synthesis. In contrast, conditions with excess $\mathrm{H}_{2}\left(\mathrm{H}_{2} / \mathrm{O}_{2}\right.$ ratio $\left.>2\right)$ lead to $\mathrm{B}-\mathrm{PdH}_{\mathrm{x}}$ formation, which favors the formation of water. For both $\mathrm{PdH}_{\mathrm{x}}$ phases, changes in the lattice were visible by changing numbers of Pd neighbors. Pd-Pd bond expansion was observed due to $\mathrm{B}-\mathrm{PdH}_{\mathrm{x}}$ formation as reported in the literature. The XAS results are evidence for a reaction of oxygen chemisorbed on the surface with hydrogen dissolved in the palladium lattice. This phenomenon serves as an additional explanation for why a Langmuir-Hinshelwood mechanism is unable to describe the direct synthesis reaction on palladium nanoparticles. Furthermore, for an adequate description of the reaction kinetics, catalyst shape and volume has to be taken into account for metallic palladium catalysts. However, lattice hydrogen might not be the only active $\mathrm{H}$ species in this reaction system. It is very likely that different activated $\mathrm{H}$ species are present dissolved in the reaction medium or on the catalyst surface dependent on the conditions present. In order to answer the question, which $\mathrm{H}$ species is favoring the $\mathrm{H}_{2} \mathrm{O}_{2}$ formation, future experiments should be performed while altering the activated hydrogen form. This could be achieved by changing the ratio of catalyst surface to volume through particle diameter and shape. Another possibility would be the preparation of partially oxidized nanoparticles with $\mathrm{Pd}-\mathrm{PdO}$ phase mixtures or partially reduced $\mathrm{PdO}$ catalysts with a metallic $\mathrm{Pd}$ shell. These experiments will substantiate our understanding of the reaction mechanism and provide the basis for knowledge-based design of catalysts with improved activity, selectivity and long-term stability.

\section{Supporting Information}

S1 - X-ray Diffraction, S2 - (Scanning) Transmission Electron Microscopy (including EDX analysis), S3 - Liquid dosing system and the in situ cell at PETRA III P65 beamline, S4 Principal component analysis on the XANES dataset, S5 - Inductively coupled plasma optical emission spectroscopy (ICP-OES), S6 - Exemplary EXAFS fits

\section{Acknowledgments}

We would like to thank the Helmholtz Association for funding within the program Science and Technology of Nanosystems (STN). Parts of this research were carried out at the light source PETRA III at DESY, a member of the Helmholtz Association (HGF). Furthermore, we would like to thank the staff working at the beamline P65, especially Dr. Roman Chernikov and Mathias Herrmann, for an exceptionally well organized beam time and the constant support during our measurements. TEM measurements were carried out with the support of the Karlsruhe Nano Micro Facility (KNMF), a Helmholtz Research Infrastructure at Karlsruhe Institute of Technology (KIT). ICP measurements kindly were performed by Herrmann Köhler with the help of Manuel Gentzen from the Institute of Catalysis Research and Technology (IKFT) at KIT.

\section{Literature}

[1] Campos-Martin, J. M.; Blanco-Brieva, G.; Fierro, J. L. G. Hydrogen Peroxide Synthesis: An Outlook Beyond the Anthraquinone Process. Angewandte Chemie - International Edition 2006, 45, 6962-6984. 
[2] Lunsford, J. H. The Direct Formation of $\mathrm{H} 2 \mathrm{O} 2$ from $\mathrm{H} 2$ and $\mathrm{O} 2$ over Palladium Catalysts. Journal of Catalysis 2003, 216, 455-460.

[3] Samanta, C. Direct Synthesis of Hydrogen Peroxide from Hydrogen And Oxygen: An Overview of Recent Developments in the Process. Applied Catalysis A 2008, 350, 133149.

[4] Dittmeyer, R.; Grunwaldt, J. D.; Pashkova, A. A Review of Catalyst Performance and Novel Reaction Engineering Concepts in Direct Synthesis of Hydrogen Peroxide. Catalysis Today 2015, 248, 149-159.

[5] Edwards, J. K.; Freakley, S. J.; Lewis, R. J.; Pritchard, J. C.; Hutchings, G. J. Advances in the Direct Synthesis of Hydrogen Peroxide from Hydrogen and Oxygen. Catalysis Today 2015, 248, 3-9.

[6] Anastas, P. T.; Warner, J. C. In Green Chemistry: Theory and Practice, Oxford University Press: New York, 1998; p.30.

[7] Landon, P.; Collier, P. J.; Carley, A. F.; Chadwick, D.; Papworth, A. J.; Burrows, A.; Kiely, C. J.; Hutchings, G. J. Direct Synthesis of Hydrogen Peroxide from H2 and O2 Using Pd and Au Catalysts. Physical Chemistry Chemical Physics 2003, 5, 1917-1923.

[8] Freakley, S. J.; He, Q.; Harrhy, J. H.; Lu, L.; Crole, D. A.; Morgan, D. J.; Ntainjua, E. N.; Edwards, J. K.; Carley, A. F.; Borisevich, A. Y.; Kiely, C. J.; Hutchings, G. J. PalladiumTin Catalysts for the Direct Synthesis of H2O2 with High Selectivity. Science 2016, 351, 965-968.

[9] Biasi, P.; Mikkola, J. P.; Sterchele, S.; Salmi, T.; Gemo, N.; Shchukarev, A.; Centomo, P.; Zecca, M.; Canu, P.; Rautio, A. R.; Kordàs, K. Revealing the Role of Bromide in the $\mathrm{H} 2 \mathrm{O} 2$ Direct Synthesis with the Catalyst Wet Pretreatment Method (CWPM). AlChE Journal 2017, 63, 32-42.

[10] Ouyang, L.; Tian, P. F.; Da, G. J.; Xu, X. C.; Ao, C.; Chen, T. Y.; Han, Y. F. The Origin of Active Sites for Direct Synthesis of $\mathrm{H} 2 \mathrm{O} 2$ on $\mathrm{Pd} / \mathrm{TiO} 2$ Catalysts: Interfaces of $\mathrm{Pd}$ and PdO Domains. Journal of Catalysis 2015, 321, 70-80.

[11] Ouyang, L.; Da, G. J.; Tian, P. F.; Chen, T. Y.; Xu, J.; Han, Y. F. Insight into Active Sites of $\mathrm{Pd}-\mathrm{Au} / \mathrm{TiO} 2$ Catalysts in Hydrogen Peroxide Synthesis Directly from $\mathrm{H} 2$ and $\mathrm{O} 2$. Journal of Catalysis 2014, 311, 129-136.

[12] Arrigo, R.; Schuster, M. E.; Xie, Z.; Yi, Y.; Wowsnick, G.; Sun, L. L.; Hermann, K. E.; Friedrich, M.; Kast, P.; Hävecker, M.; Knop-Gericke, A.; Schlögl, R. Nature of the N-Pd Interaction in Nitrogen-Doped Carbon Nanotube Catalysts. ACS Catalysis 2015, 5, 27402753.

[13] Arrigo, R.; Schuster, M. E.; Abate, S.; Giorgianni, G.; Centi, G.; Perathoner, S.; Wrabetz, S.; Pfeifer, V.; Antonietti, M.; Schlögl, R. Pd Supported on Carbon Nitride Boosts the Direct Hydrogen Peroxide Synthesis. ACS Catalysis 2016, 6, 6959-6966. 
[14] Plauck, A.; Stangland, E. E.; Dumesic, J. A.; Mavrikakis, M. Active Sites and Mechanisms for $\mathrm{H} 2 \mathrm{O} 2$ Decomposition over Pd Catalysts. Proceedings of the National Academy of Sciences 2016, 113, E1973-E1982.

[15] Tian, P.; Ouyang, L.; Xu, X.; Ao, C.; Xu, X.; Si, R.; Han, Y. F. The Origin of Palladium Particle Size Effects in the Direct Synthesis of H2O2: Is Smaller Better? Journal of Catalysis 2017, 349, 30-40.

[16] Arrigo, R.; Schuster, M. E.; Abate, S.; Wrabetz, S.; Amakawa, K.; Teschner, D.; Freni, M.; Centi, G.; Perathoner, S.; Hävecker, M.; Schlögl, R. Dynamics of Palladium on Nanocarbon in the Direct Synthesis of H2O2. ChemSusChem 2014, 7, 179-194.

[17] Lee, J. W.; Kim, J. K.; Kang, T. H.; Lee, E. J.; Song, I. K. Direct Synthesis of Hydrogen Peroxide from Hydrogen and Oxygen over Palladium Catalyst Supported on Heteropolyacid-Containing Ordered Mesoporous Carbon. Catalysis Today 2016, 293, 4955.

[18] Blanco-Brieva, G.; Montiel-Argaiz, M.; Desmedt, F.; Miquel, P.; Campos-Martin, J. M.; Fierro, J. L. G. Effect of the Acidity of the Groups of Functionalized Silicas on the Direct Synthesis of H2O2. Topics in Catalysis 2017, 60, 1151-1155.

[19] Tu, R.; Li, L.; Zhang, S.; Chen, S.; Li, J.; Lu, X. Carbon-Modified Mesoporous Anatase/TiO2 (B) Whisker for Enhanced Activity in Direct Synthesis of Hydrogen Peroxide by Palladium. Catalysts 2017, 7, 175.

[20] Seo, M. G.; Lee, D. W.; Han, S. S.; Lee, K. Y. Direct Synthesis of Hydrogen Peroxide from Hydrogen and Oxygen over Mesoporous Silica-Shell-Coated, PalladiumNanocrystal-Grafted SiO2 Nanobeads. ACS Catalysis 2017, 7, 3039-3048.

[21] Biasi, P.; Garcia-Serna, J.; Bittante, A.; Salmi, T. Direct Synthesis of Hydrogen Peroxide in Water in a Continuous Trickle Bed Reactor Optimized to Maximize Productivity. Green Chemistry 2013, 15, 2502-2513.

[22] Pashkova, A.; Svajda, K.; Dittmeyer, R. Direct Synthesis of Hydrogen Peroxide in a Catalytic Membrane Contactor. Chemical Engineering Journal 2008, 139, 165-171.

[23] Ratchananusorn, W.; Gudarzi, D.; Turunen, I. Catalytic Direct Synthesis of Hydrogen Peroxide in a Novel Microstructured Reactor. Chemical Engineering and Processing: Process Intensification 2014, 84, 24-30.

[24] Inoue, T.; Adachi, J.; Ohtaki, K.; Lu, M.; Murakami, S.; Sun, X.; Wang, D. F. Direct Hydrogen Peroxide Synthesis Using Glass Microfabricated Reactor-Paralleled Packed Bed Operation. Chemical Engineering Journal 2015, 278, 517-526.

[25] Selinsek, M.; Bohrer, M.; Vankayala, B. K.; Haas-Santo, K.; Kraut, M.; Dittmeyer, R. Towards a New Membrane Micro Reactor System for Direct Synthesis of Hydrogen Peroxide. Catalysis Today 2016, 268, 85-94. 
[26] Pashkova, A.; Greiner, L.; Krtschil, U.; Hofmann, C.; Zapf, R. Direct Synthesis of Hydrogen Peroxide over Supported Pd Catalysts: Turning to Dense CO2 as an Alternative Solvent. Applied Catalysis A: General 2013, 464, 281-287.

[27] Edwards, J. K.; Solsona, B.; Ntainjua, E.; Carley, A. F.; Herzing, A. A.; Kiely, C. J.; Hutchings, G. J. Switching Off Hydrogen Peroxide Hydrogenation in the Direct Synthesis Process. Science 2009, 323, 1037-1041.

[28] García-Serna, J.; Moreno, T.; Biasi, P.; Cocero, M. J.; Mikkola, J.-P.; Salmi, T. O. Engineering in Direct Synthesis of Hydrogen Peroxide: Targets, Reactors and Guidelines for Operational Conditions. Green Chemistry 2014, 16, 2320-2343.

[29] Voloshin, Y.; Halder, R.; Lawal, A. Kinetics of Hydrogen Peroxide Synthesis by Direct Combination of $\mathrm{H} 2$ and $\mathrm{O} 2$ in a Microreactor. Catalysis Today 2007, 125, 40-47.

[30] Wilson, N. M.; Flaherty, D. W. Mechanism for the Direct Synthesis of H2O2 on Pd Clusters: Heterolytic Reaction Pathways at the Liquid-Solid Interface. Journal of the American Chemical Society 2016, 138, 574-586.

[31] Paunovic, V.; Schouten, J. C.; Nijhuis, T. A. Direct Synthesis of Hydrogen Peroxide Using Concentrated $\mathrm{H} 2$ and $\mathrm{O} 2$ Mixtures in a Wall-Coated Microchannel-Kinetic Study. Applied Catalysis A 2015, 505, 249-259.

[32] Grabow, L. C.; Hvolbæk, B.; Falsig, H.; Nørskov, J. K. Search Directions for Direct H2O2 Synthesis Catalysts Starting from Au12 Nanoclusters. Topics in Catalysis 2012, 55, 336344.

[33] Deguchi, T.; Iwamoto, M. Catalytic Properties of Surface Sites on Pd Clusters for Direct H2O2 Synthesis from H2 and O2: A DFT Study. The Journal of Physical Chemistry C 2013, 117, 18540-18548.

[34] Staykov, A.; Kamachi, T.; Ishihara, T.; Yoshizawa, K. Theoretical Study of the Direct Synthesis of $\mathrm{H} 2 \mathrm{O} 2$ on $\mathrm{Pd}$ and $\mathrm{Pd} / \mathrm{Au}$ Surfaces. The Journal of Physical Chemistry $\mathrm{C}$ 2008, 112, 19501-19505.

[35] Iwasawa Y.; Asakura K.; Tada M. In XAFS Techniques for Catalysts, Nanomaterials, and Surfaces, Springer International Publishing, 2017.

[36] Grunwaldt, J.-D.; Caravati, M.; Baiker, A. Oxidic or Metallic Palladium: Which is the Active Phase in Pd-Catalyzed Aerobic Alcohol Oxidation? The Journal of Physical Chemistry B 2006, 110, 25586-25589.

[37] Ellis, P.J.; Fairlamb, I.J.; Hackett, S.F.; Wilson, K.; Lee, A.F. Evidence for the SurfaceCatalyzed Suzuki-Miyaura Reaction over Palladium Nanoparticles: An Operando XAS Study. Angewandte Chemie 2010, 122, 1864-1868.

[38] Centomo, P.; Meneghini, C.; Sterchele, S.; Trapananti, A.; Aquilanti, G.; Zecca, M. In Situ X-Ray Absorption Fine Structure Spectroscopy of a Palladium Catalyst for the Direct 
Synthesis of Hydrogen Peroxide: Leaching and Reduction of the Metal Phase in the Presence of Bromide lons. ChemCatChem 2015, 7, 3712-3718.

[39] Inoue, T.; Schmidt, M. A.; Jensen, K. F. Microfabricated Multiphase Reactors for the Direct Synthesis of Hydrogen Peroxide from Hydrogen and Oxygen. Industrial and Engineering Chemistry Research 2007, 46, 1153-1160.

[40] Edwards, J. K.; Solsona, B. E.; Landon, P.; Carley, A. F.; Herzing, A.; Kiely, C. J.; Hutchings, G. J. Direct Synthesis of Hydrogen Peroxide from H2 and $\mathrm{O} 2$ Using Tio2Supported Au-Pd Catalysts. Journal of Catalysis 2005, 236, 69-79.

[41] Schindelin, J.; Arganda-Carreras, I.; Frise, E.; Kaynig, V.; Longair, M.; Pietzsch, T.; Preibisch, S.; Rueden, C.; Saalfeld, S.; Schmid, B. Fiji: An Open-Source Platform for Biological-Image Analysis. Nature methods 2012, 9, 676-682.

[42] Solvay Chemicals, $\mathrm{HH} 056 \mathrm{H}_{2} \mathrm{O}_{2}$ Passivation Procedure, www.solvaychemicals.us.

[43] Pashkova, A.; Svajda, K.; Black, G.; Dittmeyer, R. Automated System for Spectrophotometric Detection of Liquid Phase Hydrogen Peroxide for Concentrations Up To 5 \% w/w. Review of Scientific Instruments 2009, 80, 055104.

[44] DETHERM, Thermophysical Properties of Pure Substances \& Mixtures, http://isystems.dechema.de/detherm/detherm.php.

[45] Ravel, B.; Newville, M. ATHENA, ARTEMIS, HEPHAESTUS: Data Analysis for X-Ray Absorption Spectroscopy Using IFEFFIT. Journal of synchrotron radiation 2005, 12, 537541.

[46] Rehr, J. J.; Albers, R. C. Theoretical Approaches to X-Ray Absorption Fine Structure. Reviews of modern physics 2000, 72, 621.

[47] Bugaev, A. L.; Guda, A. A.; Lomachenko, K. A.; Srabionyan, V. V.; Bugaev, L. A.; Soldatov, A. V.; Lamberti, C.; Dmitriev, V. P.; van Bokhoven, J. A. Temperature-and Pressure-Dependent Hydrogen Concentration in Supported Pdh X Nanoparticles by Pd k-Edge X-Ray Absorption Spectroscopy. The Journal of Physical Chemistry C 2014, 118, 10416-10423.

[48] Davis, R.; Landry, S.; Horsley, J.; Boudart, M. X-Ray-Absorption Study of the Interaction of Hydrogen with Clusters of Supported Palladium. Physical Review B 1989, 39, 10580.

[49] McCaulley, J. A. In-Situ X-ray Absorption Spectroscopy Studies of Hydride and Carbide Formation in Supported Palladium Catalysts. The Journal of Physical Chemistry 1993, 97, 10372-10379.

[50] Bugaev, A. L.; Guda, A. A.; Lazzarini, A.; Lomachenko, K. A.; Groppo, E.; Pellegrini, R.; Piovano, A.; Emerich, H.; Soldatov, A. V.; Bugaev, L. A.; Dmitriev, V. P.; van Bokhoven, J. A.; Lamberti, C. In Situ Formation of Hydrides and Carbides in Palladium Catalyst: When XANES Is Better than EXAFS and XRD. Catalysis Today 2017, 283, 119-126. 
[51] Waser, J.; Levy, H. A.; Peterson, S. W. The Structure of PdO. Acta Crystallographica 1953, 6, 661-663.

[52] Suleiman, M.; Jisrawi, N.; Dankert, O.; Reetz, M.; Bähtz, C.; Kirchheim, R.; Pundt, A. Phase Transition and Lattice Expansion during Hydrogen Loading of Nanometer Sized Palladium Clusters. Journal of alloys and compounds 2003, 356, 644-648.

[53] Keresszegi, C.; Grunwaldt, J.-D.; Mallat, T.; Baiker, A. In Situ EXAFS Study on the Oxidation State of $\mathrm{Pd} / \mathrm{Al} 2 \mathrm{O} 3$ and $\mathrm{Bi}-\mathrm{Pd} / \mathrm{Al} 2 \mathrm{O} 3$ during the Liquid-Phase Oxidation of 1Phenylethanol. Journal of Catalysis 2004, 222, 268-280.

[54] Flanagan, T. B.; Oates, W. The Palladium-Hydrogen System. Annual Review of Materials Science 1991, 21, 269-304.

[55] Zlotea, C.; Cuevas, F.; Paul-Boncour, V.; Leroy, E.; Dibandjo, P.; Gadiou, R.; Vix-Guterl, C.; Latroche, M. Size-Dependent Hydrogen Sorption in Ultrasmall Pd Clusters Embedded in a Mesoporous Carbon Template. The Journal of American Chemical Society 2010, 132, 7720-7729.

[56] Newton, M. A.; Belver-Coldeira, C.; Martínez-Arias, A.; Fernández-García, M. Dynamic In Situ Observation of Rapid Size and Shape Change of Supported Pd Nanoparticles during CO/NO Cycling. Nature Materials 2007, 6, 528.

[57] Rose, A.; Maniguet, S.; Mathew, R. J.; Slater, C., Yao, J.; Russell, A. E. Hydride Phase Formation in Carbon Supported Palladium Nanoparticle Electrodes Investigated Using In Situ EXAFS and XRD. Physical Chemistry Chemical Physics 2003, 5, 3220-3225.

[58] Manchester, F. D.; San-Martin, A.; Pitre, J. M. The H-Pd (Hydrogen-Palladium) System. Journal of Phase Equilibria 1994, 15, 62-83.

[59] Teschner, D.; Borsodi, J.; Wootsch, A.; Révay, Z.; Hävecker, M.; Knop-Gericke, A.; Jackson, S. D.; Schlögl, R. The Roles of Subsurface Carbon and Hydrogen in PalladiumCatalyzed Alkyne Hydrogenation. Science 2008, 320, 86-89. 